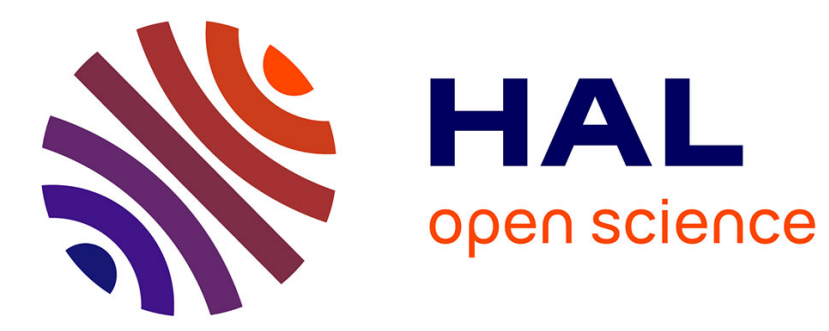

\title{
The heterogeneity of animal spirits: a first taxonomy of entrepreneurs with regard to investment expectations
}

Michaël Lainé

\section{To cite this version:}

Michaël Lainé. The heterogeneity of animal spirits: a first taxonomy of entrepreneurs with regard to investment expectations. Cambridge Journal of Economics, 2016, 10.1093/cje/bew039 . hal01744745

\section{HAL Id: hal-01744745 \\ https://hal.science/hal-01744745}

Submitted on 27 Mar 2018

HAL is a multi-disciplinary open access archive for the deposit and dissemination of scientific research documents, whether they are published or not. The documents may come from teaching and research institutions in France or abroad, or from public or private research centers.
L'archive ouverte pluridisciplinaire HAL, est destinée au dépôt et à la diffusion de documents scientifiques de niveau recherche, publiés ou non, émanant des établissements d'enseignement et de recherche français ou étrangers, des laboratoires publics ou privés. 


\section{The heterogeneity of animal spirits: a first taxonomy of entrepreneurs with regard to investment expectations Michaël Lainé}

\section{Introduction}

Entrepreneurs are market-makers (Casson 2000, 2005) and yet "the theoretical firm is entrepreneurless" (Baumol 1968: 66). "How much do individual managers matter for firm behavior and economic performance? Research in finance and economics so far has given little consideration to this question" (Bertrand and Schoar 2003: 1170), and when it actually did, it relied only on "objective factors" like education and age (Ibid.). However, entrepreneurs' subjectivity is at the core of the economy. Their role is to bring about change by engaging in innovation (Schumpeter 1934), experimenting new knowledge (Metcalfe 2006), creating new opportunities that would not exist otherwise (Shane and Venkataraman 2000), all features that imply thinking differently from one another, that is being heterogeneous.

Because of its focus on rationality, mainstream economics can barely answer the fundamental question: "How and why do entrepreneurs invest?" In matters of productive investments, rationality is beside the point, since there is very little basis on which to ground calculation. Entrepreneurs resort to a "spontaneous optimism", an "urge to action" that Keynes dubbed "animal spirits" (Keynes 1936). Therefore, one cannot answer such a question without properly assessing entrepreneurs' heterogeneity, since entrepreneurs behave differently in apparently similar situations. Following Keynes, we argue that this heterogeneity involves entrepreneurial affect (the "optimism", "whim" and "sentiment" of animal spirits). The aim of this paper is to propose a first attempt at a taxonomy of entrepreneurs with regard to investment expectations, which involves this aspect. In spite of being built on Keynes's insights (as a starting point), it will go beyond, since the indications left by Keynes in his presentation of animal spirits are rather scanty (Marchionatti 1999, Dow and Dow 2011). To our knowledge, this paper will offer the first empirical assessment of heterogeneous animal spirits. We start from Keynes because of his focus on fundamental uncertainty and the need for affective expectations ("animal spirits"). We go beyond in the sense that we try to draw on modern economic, psychological, entrepreneurial 
literatures consistent with his theory in order to derive a general theory of investment expectations on which to ground our taxonomy.

A taxonomy should be analytical, and not merely descriptive. Its purpose is to disentangle to a certain extent the influence of all possible causes given that the same causes do not have the same consequences on each and every entrepreneur. In other words, general conclusions may hide complex phenomena; conclusions may differ from one type of entrepreneur to another. We cannot suppose that animal spirits are the same for all entrepreneurs. A taxonomy offers an assessment of entrepreneurs' subjectivity, i.e. of their diverse ways to expect. Therefore, it goes beyond the mere clustering of data by also linking a set of independent variables to another set of dependent variables (here pertaining to expectations in matters of productive investments).

Entrepreneurship has quite extensively studied entrepreneurs' heterogeneity so far, but not with regard to productive investment expectations. Most scholars seem to have focused more on the differences between entrepreneurs and non-entrepreneurs - e.g. Shane, Locke and Collins 2003, Chell 2008, Johnson 1990, Robinson et al. 1991, Busenitz and Barney 1997, Begley and Boyd 1987. Various taxonomies of entrepreneurs have been proposed, revolving around motivations, skills (education, experience) and management styles (ways of thinking) as independent variables in order to account for performance, practices, innovation and perception of opportunities (the dependent variables) - see Woo, Cooper and Dunkelberg 1991, Filion 2000, Tang, Tang and Lohrke 2008, for surveys, and Smith 1967, Smith and Miner 1983 for pioneering studies. Alas, to date, despite the growing interest in affect, no specific taxonomy revolving around it has been proposed.

In our view, the best way to avoid creating a statistical artifact is to be as comprehensive as possible, that is to include virtually all potential causal factors of investment decisions as classification variables. Thus, we will heavily draw on past research on entrepreneurs' subjectivity, from Austrian economics to Post-Keynesianism and the growing strand of research 
on entrepreneurial affect (e.g. Baron 2008, Foo et al. 2013), since the argument goes that it influences opportunities' identification and evaluation, risk-taking propensities, and, generally speaking, cognition (e.g. Lerner and Keltner 2010, Podoynitsina et al. 2012, Hayton and Cholakova 2012, Baron, Hmielski and Henry 2012, Foo 2011). Consequently, our classification variables will not only encompass motivations, skills and management styles, but also dispositional affect. Of course, we do not claim to offer the definitive taxonomy of entrepreneurs. Rather, given the inherent limitations of our approach, we consider our work as a speculative experiment designed to explore the feasibility of deriving an assessment of heterogeneity on all relevant material that can be collated from various sources. In other words, we consider it as the first step towards a useful taxonomy. Our hope is to open discussion, not to close it.

The rest of the paper will proceed as follows. In the second section, we will first of all give proper definitions and expound our theoretical framework. In the third section, we'll present our research design and methodology. In particular, we will present which variables we retained for our study. Then we will introduce our results and the corresponding taxonomy. Finally, we'll conclude by discussing about the limitations of our research and the directions of future research.

\section{Theoretical framework}

Our central claims are twofold: 1) investment expectations are highly subjective, 2) subjectivity is, inherently, diverse. Thus, heterogeneity matters and it has many dimensions. After some crucial definitions, we'll see why fundamental uncertainty entails the need for heterogeneous, subjective entrepreneurs, and how affect plays a significant role in coping with uncertainty. Finally, we'll draw on interactionism in order to see what triggers affect.

\subsection{Definitions}


Albeit no consensus exists (Chell 2008), we will retain this definition, since our aim is to know what drives investment: an entrepreneur is someone who makes investment decisions, thus engaging the survival of his/her company.

When talking about investment, we do not refer to speculative investment (stocks, bonds and so on) but to "productive" one, aimed at creating or acquiring means of production, like warehouses, machine-tools, computers, patents, etc.

Like every expectation, an investment expectation comprises two faces. On the one side, it pertains to a prediction. On the other, to a decision. This was most clearly seen by Keynes, who wrote that a long-term expectation consists of "estimating the prospects of investment" and “decisions about" them (Keynes 1936: 161).

Motivation is entrepreneurs' driving force - the goal they pursue.

Affect comprises emotions, feelings and moods. Traditionally, emotions are seen as providing the "go/no go" signal necessary for action (Zajonc 1998). According to one popular theory in neuroscience, the somatic marker hypothesis, an emotion is an action program (Damasio 2009). It consists of alterations of the body; its cognitive sequel is called a "feeling" (Koenigs and Adolph 2009). An emotion has many features (Nussbaum 2001, Elster 1998, De Souza 1990, Lerner and Keltner 2010): aboutness (it has an object), valence (i.e. a connection to a positive or negative evaluation), intensity, physiological expression (e.g. blush, voice alteration), cognitive prior (it is based in beliefs, no matter how crude), appraisal tendency (it

tends to influence further cognition) and action tendency (it predisposes to a specific action). A mood is also called a "background emotion", for it has no precise object.

Cognition pertains to "true/false" questions (Zajonc 1998).

Skills are here defined as a combination of education and experience.

\subsection{The key role of heterogeneous entrepreneurs}


General conclusions may conceal complex phenomena. The same causes may not have the same effects, depending on the sub-category of entrepreneurs to which they apply. There are two cases in point: 1) the general population displays no statistical link between the independent variables and the dependent ones, yet by fragmenting and clustering data into subcategories, one sub-group may appear to display a significant link between such and such variables with, say, an $\mathrm{R}$ of .62, while another sub-group of equal importance will have an $\mathrm{R}$ of -.62, thus cancelling out each other; 2) some "causal factor" may seem to exert a slender influence, while its importance might be crucial for one sub-group and totally insignificant for others (thus a general average can't help but mitigate this very specific effect).

Besides, there are other reasons why heterogeneity should matter. Austrian economics has long stressed the centrality of uncertainty in economic life. Were the future probabilistically predictable, entrepreneurs would have no peculiar role to play. They would act like gamblers. If profits could be calculated with probabilistic certainty, all entrepreneurs would undertake the same investment projects, those yielding the highest payoffs, provided that they could afford it. By so doing, they will wage a war on prices since it suffices to offer a slightly reduced price to steal the limelight and reap higher profits. Since all competitors are bound to reason the same way lest they are wiped out the market, entrepreneurs end up making no profit, a conclusion already made by Walras (1888) and Debreu (1983). The same conclusion holds even if information is incomplete, provided that entrepreneurs update their beliefs thanks to Bayes's rule. Thus, "profit arises out of the inherent, absolute unpredictability of things, out of the sheer, brute fact that the results of human activity cannot be anticipated and then only in so far as even a probability calculation in regard to them is impossible and meaningless" (Knight, 1921: 311). Profit is the reward for making better expectations than competitors, and the signal for the reallocation of resources (Foss and Klein, 2011, Foss et al. 2007). Fundamentally, it pertains to entrepreneurs' heterogeneity. Investment projects are, to a great extent, unique. Consequently, they cannot be subject to 
probability calculus, since it would require too vast an amount of data. Investment projects fall within "crucial experiences": "Napoleon could not repeat the battle of Waterloo a hundred times in the hope that, in a certain proportion of cases, the Prussians would arrive too late. [...] Had he won, repetition would for a long time have been unnecessary; when he lost, repetition was impossible" (Shackle 1955: 25). Furthermore, if we could assess the quality of knowledge prior to its acquisition, we would enter an infinite regress, since it would also require assessing the quality of such an assessment, which in turn, etc. We seem to have no choice but to conclude that "profit depends on the radical and inherent unpredictability of human affairs; on men's power and ambition to alter their economic environment and not be content merely to respond to it" (Ibid: 92). For one thing, entrepreneurs create opportunities that would not exist otherwise. "Entrepreneurial discovery is as much about problem finding as problem solving" (Zahra et al. 2009: 522). They display unique abilities in exploiting such opportunities (Shane and Venkataraman 2000) and devise new means-ends relationships, "a gift individuals enjoy in quite different degrees" (Kirzner 1979: 148). Arguably the most famous Austrian economist to date, Schumpeter (1934) put forth the crucial role of entrepreneurs in bringing about innovation. He distinguished between five types of innovation: new products, new methods of production, new sources of supply, new markets and new ways to organize business. While he was also careful to distinguish the entrepreneur from the inventor, he ascribed the creation of "new economic form" to the former. Thus, even if the entrepreneur may not be the inventor of a new product or process, it's up to her to give this innovation an economic form; in a nutshell: to embody it. Her role is to give life to "dead possibilities", which exist only in a dormant state. And nothing is more heterogeneous than the capacity to embody innovation, since it requires a mix of vision, strong will, ability to lead, move forward and not be deterred by adverse circumstances (Ibid.). As a matter of fact, the prevalent, current definition of entrepreneurship by proponents of Austrian economics refers to "the exercise of judgment over resource uses under uncertainty" (Foss et al. 2007: 1166, see also Casson and Godley 2005). 


\subsection{The need for affect so as to cope with uncertainty}

Owing to fundamental uncertainty, an entrepreneur has no choice but to rely on her subjectivity. However, can this subjectivity take the form of a subjective probability calculus, be it unconscious? In his Treatise on Probability, Keynes kept on castigating the "mathematical charlatanry" of those using probability calculus as a guide of conduct, since it implies that "constant causes are always at work and assert themselves in the long run" (Keynes 1921: 366): "there is no direct relation between the truth of a proposition and its probability" (Ibid.: 356, see also O’Donnell 1990, Carabelli 1988). The world is non-ergodic, meaning unique and nonrepetitive (Davidson 1991, 1996). Consequently, the basis for an exact calculation does not exist in matters of investments. Instead, most of the time entrepreneurs resort to their "animal spirits", depicted as "spontaneous optimism", "sentiment", "whim", "urge to action", "nerves", “spontaneous activity" (Keynes 1936). This definition pertains to both sides of investment expectations: prediction ("optimism", later on defined as an over-estimation) and decision ("urge to action", "spontaneous activity"). The lexical field clearly pertains to affect: "optimism", "sentiment", "whim", "fear", "hope"... Thus, to cope with the fact that "our knowledge of the future is fluctuating, vague and uncertain" (Keynes 1937: 213), entrepreneurs rely on affective expectations: "it is our innate urge to activity which makes the wheels go round, our rational selves choosing between the alternatives as best we are able, calculating where we can, but often falling back for our motive on whim or sentiment or chance" (Keynes 1936: 163, our emphasis, see also Akerlof and Shiller 2009). As with Austrian economics, fundamental uncertainty takes center stage; it all the less surprising as Shackle (1967: 130) expressed his utmost admiration for Keynes's $12^{\text {th }}$ chapter of the General Theory, where animal spirits are depicted. The difference lies in Keynes's theory of how entrepreneurs cope with such uncertainty, which bestows a positive role on affective expectations since they "make the wheels go round". Indeed, "we should not conclude from this that everything depends on waves of irrational psychology", for "if 
the animal spirits are dimmed and the spontaneous optimism falters, leaving us to depend on nothing but a mathematical expectation, enterprise will fade and die" (Keynes 1936: 162).

It should be noted that, for Keynes, there is duality of reasoning when it comes to investment expectations: our "rational selves [...] calculat[e] where we can but often fall back on" animal spirits. So, there seems to be calculation on the one hand, and animal spirits on the other. The default mode is that of animal spirits: "Most, probably, of our decisions to do something positive . . . can only be taken as a result of animal spirits" (Keynes 1936: 161, emphasis added), as opposed to "reasonable calculation" or "mathematical expectation". Keynes did not deny outright that the latter may have a slight role to play. He went even so far as maintaining that "individual initiative will only be adequate when reasonable calculation is supplemented and supported by animal spirits" (Ibid.: 162, emphasis added). Thus, Keynes appears to have outlined three kinds of investment expectations: animal spirits alone (most expectations), reasonable or mathematical calculation alone (very seldom), and "reasonable calculation supplemented and supported by animal spirits" (some expectations, supposedly the most successful ones).

Finally, we should emphasize that "animal spirits" are not to be confused with "confidence". Confidence is a subjective assessment of whether animal spirits are right or wrong.

The same kind of conclusion was arrived at by some proponents of bounded rationality. While Herbert Simon, the founder of this stream of research, did not talk much about affect, some of his disciples give it a pivotal role (e.g. Kaufman 1999, Hanoch 2002, Earl 2005). "Bounded rationality" refers to the limited reasoning power of individuals in the face of the inherent complexity of the world (Simon 1979, 1990). Instead of maximizing, people try to find a satisficing solution (Simon 1955, 1956, 1959). Instead of calculating probabilities, they solve problems by adaptive, "selective trial and error, using heuristic rules derived from previous experience", a process called "procedural rationality" (Simon 1965: 186). In this regard, modern proponents of Simon's work view emotions as the satisficing mechanism par excellence (Hanoch and Muramatsu 2005). Emotions would assist the reasoning process and 
make satisficing options more salient. They would trigger necessary mental shortcuts. "By restricting the range of options considered (reducing the load on short and long term memory), by focusing on certain variables (certain stimuli receive higher ranking order), and by initiating and terminating the evaluation process (working as a satisficing mechanism), emotions supplement the insufficiencies of reason" (Hanoch 2002: 7).

Furthermore, many influential papers in neuroscience have stressed the role of emotions as "provid[ing] a metric for the decision maker in weighing various options for action or choice" (Phelps, 2009). This is the central claim of the famous "somatic marker hypothesis" (Bechara et al., 2000, Bechara and Damasio 2005). Emotions seem to mark the consequences, positive or negative, attached to past decisions. Thus, they may be guides for action - necessary for the intelligence of our decisions. That's why Damasio (2009) asserts that emotions consist of an action program: traces of past consequences ("marks") are left in the body ("soma" in ancient Greek) and reactivated rapidly so as to assess the value of an event. "[S]omatic markers do not deliberate for us. They assist the deliberation process by highlighting some options (either dangerous or favorable), and eliminating them rapidly from subsequent consideration. You may think of it as a system for automated qualification of predictions" (Damasio, 1994: 174).

Somatic markers are activated by "inducers", aka "emotionally competent stimulus" (Damasio 2003). There are two kinds of inducers, depending on whether they originate from the outer world ("primary inducers", e.g. the presence of a bear, or news from a financial collapse) or the inner world ("secondary inducers", e.g. thoughts, memories, flights of fancy). In both cases, the neural route differs. Somatic markers associate, in the form of dispositions, two sorts of memories: factual knowledge and bioregulatory states (Damasio 2010). Dispositions are what make these markers quick and efficient, since they consist of some light program that would enable the brain to re-experience the same bioregulatory state that was triggered in the first place by way of a few 
traces, instead of storing each past event with all its details. Thus, somatic markers "have been connected, by learning, to predicted future outcomes of certain scenarios" (Damasio 1994: 174). The role of the dopamine, extensively documented (e.g. Schultz 2009, Glimcher 2009, 2011a, Berthoz 2013), illustrates one of the vital functions of affect. The dopamine is released in the brain as a function of errors in predictions of rewards. If the outcome of our decision meets our informed expectation (meaning an expectation based on several trials), there is no shift in the release of dopamine (for this neuromodulator is constantly firing at a slow rate). If we enjoy a better reward, there is a burst of dopamine. Conversely, if the result is under our expectation, no dopamine is released at all. A very potent hormone, the dopamine generates an affective state: joy, excitement or satisfaction on the one hand, disappointment or frustration on the other. The valence of these affective states is informative: one or many of our goals are, or seem bound to be, met above or under expectation. Yet, prediction errors can stem from two sources: unrealistic beliefs and unrealistic aspirations. By signaling that our beliefs and aspirations are not adapted to the circumstances, the dopamine (and the affective states it generates) sends an incentive to re-examine or update them.

That's why this neuromodulator is generally seen as the building block of learning mechanisms: "the role of dopamine is to update the "value" that humans and animals attach to different actions and stimuli, which in turn affects the probability that such actions will be chosen" (Caplin and Dean 2008: 664). Anytime an electric signal called "action potential" occurs in response to a given stimuli, the pathway it takes is tagged. Along this way, all tagged synapses (the connection spaces between neurons) are strengthened due to several chemical reactions (LeDoux 2002), among which dopamine plays a key role. It appears that these synapses are strengthened in the presence of dopamine and weakened in its absence (Glimcher 2011b).

The errors from past experience are discounted. The more remote the experience, the lesser its present value. "The dopamine firing rates could be well-described as computing an 
exponentially weighted sum of previous rewards and subtracting from that value the magnitude of the most recent reward" (Glimcher 2011b: 15651). However, the shape of the discounting function remains a moot point, since Kobayashi and Schultz (2008) argue that it is hyperbolic.

An interesting feature about dopamine is the dissymmetry between positive prediction errors (the reward is higher) and negative ones (it is lower). The shift in firing rates appear much stronger in case of positive errors (Schultz et al. 1997). A plausible explanation of this discrepancy involves the conjoined action of a second system for the negative part of prediction errors (Glimcher 2011b).

Thus, emotions may function either as a filter (in that it renders some information more salient and wipes away other news) or as a revelator, to signal a discrepancy between the current state of affairs and some vital objective (Kaufman 1999, Grichnik, Smeja and Welpe 2010).

Of course, it is not enough to examine the role of affect in expectations and decision-making. The next step is to have a look at its causes.

\subsection{Personality as a conditional generative process of affect}

Next, to delve into how animal spirits engender affective states, we will use a widely hailed psychological theory, "interactionism". According to interactionism, personality generates affects and cognitions depending on the context (Chell 2008). More precisely, the "personality system" refers to an enduring state, both consistent and variable across situations - on the whole, the person tends to behave in a distinctive manner. This is called the "Type 1 consistency" (Mischel 2004). It gives rise to a "personality state", more fleeting, which varies according to the circumstances but stable within a given circumstance, the "Type 2 consistency". "An individual might be higher than most people in a trait in some situations but also distinctively lower than most in other situations. On the other hand, individuals also showed temporal stability in their behavior within particular situations that were highly similar and formed a type, or 'functional equivalence class', of situations" (Mischel 2004: 5-6). The personality system is then a stable 
pattern of variability that "mediates how the individual selects, construes and processes information and generates behaviors" (Mischel and Shoda 1995: 246). So to speak, the personality system is what dynamically relates a situation to a behavior:

$B=f(P E)$

$B$ being the behavior, $P$ the personality system and $E$ the situation (or environment).

This system organizes relations of cognitions and affects according to distinctive "if... then" profiles. In other words, specific features of the situation at hand activate a set of internal reactions - both cognitive and affective, by which the "situation" is more than the mere "stimuli" of behaviorism, since it crucially depends on the perceiver's subjective constructs -, which in turn lead to a behavior. Thoughts are affect-laden. The personality system can be further decomposed into basic units, dubbed "cognitive-affective units" (CAUs), which are dynamically processed, re-enacted and interconnected when the same class of situation recurs: $B=f(C A U s E)$

And $C A U s=M R$

$M$ being the motivations defined as the set of enduring goals and $R$ the various representations, which comprise the image of the self, beliefs, knowledge and memories. In this framework, what Mischel calls a "trait" refers to the visible, relatively stable interplay of CAUs characteristic for a given person. It is thus an intermediate unit of analysis between the grand "personality system" and the basic "cognitive-affective units". We will call "trait" those networks of CAUs that do not pertain to motivations, therefore in a more restrictive sense than Mischel, in order to differentiate them. So, motivation matters since it sets the direction of behavior; traits and thinking styles matter because they influence how information is processed in order to generate behavior.

So to speak, a specific trait within the personality system is a conditional "probability" of a category of behavior in a category of contexts (Chell 2008). Here, "probability" is to be taken in 
a metaphorical meaning. Put differently, a specific trait increases the chances of generating similar behaviors in similar contexts. Of course, numerical precision and Bayesian updating are out of the question. In other terms, a given situation causes an entrepreneur's expectation through her personality. But the causal relation is one of relative (in)determinism. It is not: if situation A, then behavior B, but: if situation A, then probability $p$ of B. As a result, "it becomes possible to account simultaneously for both the invariant qualities of the underlying personality and the predictable variability across situations in some of its characteristic behavioral expressions" (Mischel and Shoda 1995: 246).

In this theoretical framework, a "situation" or "context" does not necessarily refer to an external stimulus. It may also refer to self-initiated ruminations, fantasies, remembrances. It highlights the fact that our decisions are highly context-dependent. Hence the need to assess investment expectations through the contexts that give rise to them given entrepreneurs' "personality systems". Consequently, we will ask our entrepreneurs what kinds of contexts drive them to invest.

For our inquiry, it has profound implications. Interactionism enables us to assess what triggers affect - i.e. personality traits, thinking styles and motivations within a personality system. It takes due count of the context, in a non-simplistic manner. The personality system functions as an affect-generative process conditional on the context. It enables a research strategy: gauging the contexts that drive entrepreneurs to invest. Furthermore, individuals widely differ in their personality systems - hence the necessity to measure this heterogeneity.

\section{Research design}

\subsection{Research question}

The purpose of the current study is to help answer the question "How and why do entrepreneurs invest?" by classifying their diverse animal spirits. In this regard, we will design a taxonomy of 
entrepreneurs along the lines of interactionism: their investment behavior stems from their motivations, styles, skills and traits depending on the context. In other words, motivations, styles, skills and traits comprise our classification, independent variables. Investment behaviors and an evaluation of the sensitivity of investment to each context comprise our dependent variables. We hope for significant patterns to emerge between these groups of variables. Of course, our classification variables do not include the dependent variables, since our aim is to see whether the latter may display a significant link with the former. We will consider that a specific pattern emerged if and only if in the aftermath of a cluster analysis our groups differ significantly with regard to these dependent variables. The following empirical analysis will thus examine the different sub-categories of entrepreneurs according to their investment expectations.

\subsection{Sample and Variable Definition}

A survey was administered from February to May 2013 to more than 8,000 French entrepreneurs from two mature industrial sectors, namely wine and spirits and apparel. Of the 908 entrepreneurs who responded, 331 gave complete answers. The questionnaire was quite long, which may explain why many respondents did not go to the end. Of these, we retained 289 entrepreneurs, because we wanted only actual entrepreneurs in our sample (a specific question asked whether they discovered and exploited new opportunities and another one asked whether they were subcontractors), and the same legal forms and firms big enough to consider genuine investment projects (defined here as a firm size of at least one employee).

Half the respondents had a sales revenue of less than 1 million euros a year. A mere $2.7 \%$ had sales revenues over 100 million. The mean value was 15.19 million euros. One fourth of our sample were the actual founders of the business. Almost one half were partners. More than eight entrepreneurs out of ten had more than 5 years of experience as entrepreneurs (mean 12.35) while one third had no prior experience as executive (mean 6.52). The mean rate of capacity utilization was $80 \%$. 
The classification variables we try to evaluate include all possible causal factors outlined by past research. Therefore, to the extent possible, we listed the choice of variables set by prior literature that may apply to investment expectations, which implied to reject some irrelevant ones, if not tinker with them. For instance, "locus of control", a feature discussed at length in entrepreneurship, does not seem to have any clear consequence as regards investment expectations. Thus, we did not incorporate it in our study. The variables were sometimes relabeled for the purpose of our questionnaire, when we had the feeling their meaning was not plain enough to laymen. When variables would appear very close we preferred to conflate them into a more general category. Remember that we had four groups of criteria: motivations, skills, management styles and traits. The specific variables, their literature sources and their corresponding measures are described below (see also Table 1).

Motivations to run a business are a widely explored topic. Indeed, a huge spate of literature tried to distinguish what motives differentiate entrepreneurs from non-entrepreneurs. We draw on this literature, despite its alleged shortcomings (Gartner 1989, Johnson 1990), because we believe the question to be misplaced, since some of these motives might be determinant for some people while being insignificant for others. Moreover, we are interested in grasping entrepreneurs' different goals, and not what makes them different from the general population. In this tradition, the most relevant features are (e.g. Brockhaus 1982, Chell 2008, Shane et al. 2003, Bazerman and Moore 2009, Filion 2000 for surveys): need for achievement, need for autonomy and independence, security (social status and valuation of money), commitment and vision. In our study, commitment and vision are conflated into a broad "in order to transform society, share and defend your vision, your project", and "need for achievement" has been relabeled "selfrealization", so that it may not overlap with the former.

Schumpeter (1934) outlined four motives: "to succeed for the sake of success itself", "the joy of creating", "delight in ventures", and "founding a private kingdom" (Ibid.). The first one can be 
linked to the thrill of competition, the will to reach glory and/or impress (Mathur 2012). "Joy of creating" can be conflated with "quest for novelty" or "the need to innovate" (Davidsson 1995, Caron 2005, Cassis 2005), since they seem complementary, into the more general: "to explore and innovate". "Delight in ventures" could be clarified and rephrased as "to take up a challenge". "Founding a private kingdom" could be rephrased into the more modern "founding a durable, thriving company". Besides, we should not underestimate the intrinsic interest of management itself (Baum and Locke 2004, Wadeson 2006). This interest could be conflated with "to produce something perfect" (Lafuente and Salas 1989) into the broad "out of love of the job and love of good work". Power can be valued for its own sake (Kirkpatrick and Locke 1991): to lead seems to be a reward in itself (Lafuente and Salas 1989). Since social status is also power, but outside the firm, we conflate the two: "to gain social status and lead". Last but not least, "valuation of money" has been further clarified "in order to enjoy life at its fullest".

Motivations to run a business were based on relative rankings. Since all motivations may appear positive and potentially relevant, the answers taken at face value would have been misleading. By allowing only three choices, we encouraged un-distorted answers. Draws were also allowed. For instance, "self-realization" and "to explore and innovate" could be both ranked highest, which implies that any potential third motivation should be ranked third.

Traditionally, entrepreneurs' skills are measured through two variables: previous experience and education (Brockhaus 1982, Woo, Cooper and Dunkelberg 1991, Zahra et al. 2009). We split the former into an assessment of the number of years spent as 1) an entrepreneur, 2) an executive. Thus, we have two variables for experience. Education is assessed by asking for the highest degree obtained. We had two supplementary items (multiple choices allowed): "many university degrees of the same ranking" (since respondents could have undertaken different studies) and "self-made man" (so that respondents may not feel ashamed if they have no or few degrees). 
As to the diverse management styles, we refer to the classical study of Filley and Aldag (1978), which outlined three types: craft, promotion, administration. For the sake of our study, since they may not be crystal-clear, we re-phrased them, respectively, into conventional-practical, innovative and technical. Thus, we assume entrepreneurs may grasp the meanings of these labels without further development. Assessments were based on a similar ranking as for motivations. Among the personality traits, none has been more studied than the famous "risk-taking propensity" (March and Shapira 1987, 1992, Shane et al. 2003, Chell 2008). Optimism has also been distinguished from self-confidence (e.g. Casson 2000, 2005, Morris et al. 2012, Shi, Tsuji and Zhang 2012, Hmielski and Baron 2009, Hayton and Cholakova 2012). The former is larger: it means the belief that events will be favorable. The latter means that events that depend on us will be favorable due to our decisions. It is a truism that both these traits may have a significant role to play when it comes to investment expectations, since they imply to evaluate future events. A robust finding is that people tend to overestimate their own skill on hard tasks but underestimate it on easy tasks. Moreover, people tend to judge themselves as better than average in familiar situations and worse than average in unfamiliar situations (Hogarth and Karaleia 2012)... Entrepreneurs with high-perceived selves would tend to overachieve and take more risks (Krueger Jr and Dickson 1994, March and Shapira 1992, Baum and Locke 2004).

Even if Keynes's animal spirits have been linked to self-confidence and optimism (Krueger Jr and Dickson 1994, Farmer 2012), they may also refer to impulsivity (we ought to bear in mind that the term often employed to describe them is "urge"). Consequently, we assumed this trait ought to be included.

Of course, entrepreneurs differ from one another in terms of creativity (Robinson et al. 1991, Filion 2000, Fillis and Rentschler 2010, Caron 2005, Hirshleifer et al. 2012). We may add attitude towards ambiguity (Ghosh and Ray 1987, Camerer and Weber 1992) under the more general heading "attitude towards uncertainty", since the latter encompasses, but cannot be 
reduced to, the former. Indeed, sources of uncertainty are numerous: ambiguity, ignorance, indeterminacy... We preferred to rate this more general attitude because we follow Schumpeter (1934) and Metcalfe (2006) in believing that entrepreneurs may feel uncertainty as an opportunity rather than a threat. One may wonder whether "risk" significantly differs from "uncertainty". What we mean by the former is the possibility of losing money (i.e. how much you value money), and by the latter not knowing what will be coming next (i.e. how much your ignorance of the future frightens you). The questions were so phrased as to make the distinction clear. For instance, entrepreneurs were asked to assess on a five-range scale how "the fact that the future is uncertain may..." with "be exciting" at one extreme and "be frightening" at the other (and "equally exciting and frightening" in the middle).In matters of productive investment, to expect implies to discover or shape opportunities and to perceive (and be willing to bear) risks. Yet, specific emotions have been outlined in the entrepreneurship literature as influencing opportunity discovery and exploitation as well as risk-taking: joy and sadness (Wellpe et al. 2012), regret (Arora, Haynie, Laurence 2013, see also Loomes and Sugden 1987), fear and anger (Podoynitsina et al. 2012). It should be noted that Keynes alluded to the "fear" of entrepreneurs, and the "depression" of enterprise. Generally speaking, angry and happy people alike are said to take more risks, whilst fearful and sad people would shun risks (Lerner and Keltner 2001, Fessler 2001, Foo 2011, Bazerman and Moore 2009).

Our aim is to grasp entrepreneurs' subjectivity. Therefore, we have no choice but to rely to a large extent on what entrepreneurs say about their real expectations. We cannot possibly observe both their affects and their actual decisions in their everyday business life. And yet, we have to bridge the gap between entrepreneurs' declarations and decisions as much as we can. If we ingenuously asked "the last time you invested, why did you invest?", the biases would have been tremendous - memory defects and distortions, doublespeak, lack of clairvoyance, etc. That's why we asked for an evaluation of what we call "independent variables" for the purpose of this study, since these variables are less subject to distortions - everyone is supposed to know what 
motivates her, how many years she spent as a manager, what her traits are, etc. Likewise, we have to use proxies for the actual decisions - what we have called, here, the "dependent variables". Since expectations are highly dependent on the context (see 2.4), it would have been pointless to ask bluntly "what was your last investment?". Instead, we found it wiser to divide our dependent variables into the diverse ways to expect and the sensitivity to each possible context. Therefore, our dependent variables will not only assess the wide array of investment behaviors per se, but also what circumstances push entrepreneurs to invest - and how strong they are. It is our contention that the combination of this behavior and the sensitivity to contexts may provide a somewhat relevant answer to our research question.

The group of investment behaviors comprises items that appeal to common sense, so that the answers may be unambiguous: to calculate profitability precisely, to delineate profit options and weight them (mathematical expectation), to revise calculation as new data crops up, to rely on her gut feelings, on experts' opinion, to reduce uncertainty, to create her market, to be at the edge of innovation, etc. Please remember that Keynes did not entirely rule out the possibility of a mathematical calculation (see section 2.3). He rather delineated three possibilities: the expectation is the result of animal spirits alone, which is the most probable case (1), reasonable or mathematical calculation alone, however rare this scenario may be (2), and "reasonable calculation supplemented and supported by animal spirits" (3). Furthermore, we cannot exclude on a priori grounds that the entrepreneurs may think of themselves as rational beings. Hence the items "calculate profitability precisely" and "delineate profit options and weight them (mathematical expectation)".

Of course, some of the "investment behaviors" might seem somehow related to motivations or traits (two sub-groups of our independent variables). For instance, "to be at the edge of innovation" could stem from a motivation to "explore and innovate". Still, this behavior may be linked to other motivations; for example, one may believe it necessary to innovate permanently, as a result of 
careful consideration, while being motivated solely by money or social status. In general, there might be a discrepancy between what an entrepreneur thinks she is in terms of motivations and traits and what she believes her duty or her role to be... For example, she may be strongly risk and uncertainty averse as a person and nonetheless believe her job requires to be less cautious. As a result, she may not seek to secure her investments at all costs, a behavior which would correspond to our "investment behavior" variable "uncertainty reduction (securing investment)". We do not see any systematic link nor any overlap between our independent and dependent variables (but there may be up to a point within groups of variables, though). Investment behaviors were assessed through a five-range scale, ranging from "strongly disagree" to "strongly agree".

As regards the contexts that drive entrepreneurs to invest, they are the classical ones outlined by the literature in economics and management: a rise in profits, a rise in sales revenues, shareholders' demands, a market expansion, a fall in interest rates, possibilities of financing, a cost increase, the signature of a new client or contract, the forecasts of experts, a lesser yield of alternative investments such as bonds, stocks, etc. However, we also had the feeling we should not exclude adverse circumstances, since the press regularly echoes investment schemes designed to solve firms' problems: a fall in profits, a fall in sales revenues or in market shares. The power of these circumstances is assessed through the frequency with which entrepreneurs claim to invest, on a scale ranging from 0 ("never") to 4 ("very often").

\section{Insert Table 1}

\subsection{Methodology}

Cluster analyzes were performed to derive types. First of all, we performed a standard method, the "k means". Then, in order to test the robustness of these first results, we implemented a second common method, a hierarchical algorithm named the "Ward method", based on a Euclidian-distance matrix. As a matter of fact, if our classification is robust, it should not be 
sensitive to the choice of method. If we obtain diverging results, we would conclude our attempt at a taxonomy is a failure. In order to assess which of the classification criteria were meaningful for the constitution of our types of entrepreneurs, we calculated the $T$-value and performed a MANOVA for each of these criteria with regard to the mean of our sample. For instance, if a given group that emerged through our cluster analyses had classification criteria that displayed statistical significance (i.e. their $T$ were above 1.964 or under -1.964 ), then we rejected the null hypothesis (i.e. we concluded this variable is responsible for the constitution of this group, among other significant variables). Otherwise, we assumed the variables were not important. MANOVA calculations were performed in order to have telltale figures, since they provide for percentages of the variance explained by the fact of belonging to the group.

So as to see whether our two clustering methods coincided, we performed another $T$-test. Thus, we could see whether the differences between the group means obtained by both methods were statistically significant. If so, we had to count the number of diverging variables. Then, we performed the calculation of a Jaccard index, a common method for comparing clusters. Given two sets $\mathrm{A}$ and $\mathrm{B}$, this index reads:

$$
J(A, B)=\frac{|A \cap B|}{|A \cup B|}
$$

The closer to 1 , the better. A value of 1 is indicative of a perfect similarity. At the very least, the index should be 0.5 , and a value of 0.75 could be considered as "good" (Hennig 2007). Of course, the threshold one uses is, to some extent, subjective. As a test of robustness, we propose the following: if any single group has a Jaccard index of less than 0.75 , then our entire classification would be rejected as statistical artifact.

Determination of the relevant number of groups or types is also a key but somewhat arbitrary decision. It is especially the case with the "k means" method. We did not want to presume a priori how many groups we should obtain. Thus, we decided to start with a very high number $(\mathrm{k}=20)$. If any group had too little a sample size to yield enough statistical power, we decided to start 
another round of clustering calculations with $k$-1, etc. until we reach a satisfactory level of statistical power for each and every group. We set this minimum sample size at 20, which corresponds to expected power and $d$ (aka "effect size") of 0.60 and 0.5 respectively. In other terms, at the very least, our probability to accept as true a false classification will not exceed 5\% and our probability to reject as false a true classification will not exceed $40 \%$, provided that the effect of belonging to a group is, as expected, "medium".

\section{Results}

We obtained 11 groups of entrepreneurs. Our results seem robust: most groups display a Jaccard index above 0.9 (see table 2).

\section{Insert Table 2 here}

We observed significant patterns between our independent and dependent variables, i.e. the fact of belonging to a group accounts for a significant proportion of the variance of some dependent variables. Thus, it would seem that being from one type of entrepreneurs influences expectations. We view these groups as ideal types (Weber 1957), that is as theoretical constructs based on empirical foundations and cornerstones, "ideal" representations towards which the reality is tending, with inevitable slight nuances due to the diversity of special cases. Given that some classification criteria may overlap, one may not exclude the possibility that there may be major and minor memberships. For instance, an entrepreneur may be a "gambler" major and a "builder" minor. Indeed, some entrepreneurs in our database actually display characteristics that may pertain to two groups (but not more, since their definition seems sufficiently clear-cut). In such a case, they belong more to a group than the other, meaning that they have more features in common with the ideal type of the first group than with the ideal type of the other group.

In the remaining part of the section, a brief description of each group will be followed by their corresponding tables containing the main statistical results (i.e. significant $\mathrm{T}$-values and 
corresponding MANOVA and delta, along with means and standard deviations). Please bear in mind that our $T$-tests are calculated with regard to the means of our general sample. In other terms, any claim should be read with the qualification "compared to the average entrepreneur". Of course, the exact description of the ideal types remain open to discussion. Although we have derived them from our statistical results, some necessary stitches may have been given by intuition and imagination. If another scholar comes with another interpretation of the same figures, we would gladly discuss it. Two tables will be found at the end of all descriptions for purposes of cross-comparison and further discussion. For each and every type of entrepreneur, the corresponding statistical table can be found in the appendix.

\section{The Neoclassical Manager}

She is the entrepreneur of standard theory. Rational, master of her emotions, little inclined to succumb to euphoria, full of courage and will, she is strongly uncertainty-averse: any time she can, she tries to tame uncertainty by probability calculus. Furthermore, she tries to swallow as much news as she can: to be aware of everything so that she may not be surprised by anything. She is not characterized by any specific motivation, since she can accommodate all. Neutral towards risk, the neoclassical entrepreneur invests so as to maximize profits.

She compares alternative investments and tries to take heed of the forecasts of experts. When she realizes that things somehow went wrong, she re-examines her opinion and can easily switch from one project to another. Less than anyone else, she is susceptible to yield to a sunk cost fallacy. In accordance with standard theory, the circumstances that entice her most to invest are: a fall in interest rates, a rise in profits, a lesser yield of alternative investments and shareholders' demands. Comparatively to her counterparts, she invests more.

\section{The Builder}

She is the entrepreneur of long-term undertaking par excellence. Very soon, she learnt that perseverance overcomes everything, that there were no obstacle that will could not overthrow. 
Fortune's reversals are so unpredictable, tribulations are such that it is better to build patiently, step by step, detail after detail, her company. Time is her surest ally. She is not the kind of entrepreneur that jeopardizes her firm on a single investment. Too bright ideas, speculative constructions of the mind are kept under suspicion. Insensitive to fads and fashions, reluctant to abstract demonstrations, she prefers concrete projects, carefully considered. She expects the worse so that she may be able to cope with it. That's why she more readily thinks in terms of affordable losses rather than expected returns. The appeal to probability calculus mirrors her cautious attitude. Her management style is technical, not innovative. The builder entrepreneur does not want to take up challenges; she is doing things with a view to leaving scars on the soil, to achieving something worth it.

Her sharpened conscience of the inherent frailty of economic life inclines her to privilege the quality of the product and the competence of her staff. Money is what makes the world go around: the builder entrepreneur will be very sensitive to possibilities of financing and a fall in interest rates, since she painfully knows for a fact how fast finance dries out. Besides, she will be obsessed by cost control: more than her counterparts, she will invest in cases of cost increase. Furthermore, rises in profits and sales revenues will particularly entice her to invest. A fall in sales revenues will look especially ominous. It is a harbinger of future disasters. Thus, it is absolutely vital to invest so as to stave off this looming prospect.

\section{The Administrator}

Strongly risk-averse, the administrator entrepreneur takes her task seriously and with circumspection. She is leery about too high ambitions and unrealistic objectives. The will to distinguish herself is rather alien to her. She is Schumpeter's "mere managing administrator". Business is business and profit is thus her primary obsession. Thus, she will not hesitate to optimize taxes. She became entrepreneur out of love for the job and in order to enjoy life at its fullest thanks to money. This kind of entrepreneur may lack vision and education, but she is reliable. She won't let her ego supersede her duty. 
She launches few novel products. Haunted by uncertainty, she will try at all costs to reduce it. Such a powerful fear will also paralyze her in face of adverse circumstances, such as a fall in profits, sales revenues or market shares. Conversely, a profit increase will be greeted as a blessing. Accordingly, she will invest more in this kind of situations. Furthermore, like her "builder" counterpart, she is particularly sensitive to possibilities of financing, be they cheap interest rates or high levels of self-financing.

\section{The Paternalistic Manager}

She is the entrepreneur of second thoughts, ruminating her past failures. The paternalistic manager believes an individual is shaped by trials and ordeals. There would be nothing like experience to know how to manage a firm. She has limited experience as an executive, preferring to focus on entrepreneurship. Pessimistic, risk-averse, she does not trust easily, beginning with herself and her employees. Therefore, she would like to control everything. She does not rely on her gut feelings, nor does she try to distinguish herself at all costs, since it can lead her to err. The paternalistic manager believes her company is a family, of which she is the head. Even if she has a protective instinct and may entertain affective relations with some or most of her employees, she is on keen on the best remedy to human fallibility: procedures. Thus, her management style is less innovative than conventional.

Above all, the paternalistic manager tries to reduce uncertainty, event at the cost of failing to seize opportunities. Overall, she under-invests. It takes a lot of thinking and tinkering to overcome her natural reluctance to engage any hefty sum. This little educated entrepreneur is most sensitive to the signature of a new contract or client, since the prospects are then concrete.

\section{The Hero}

She is the ultimate competitor. Above all, she enjoys the thrill of competition. It stimulates her, and forces her to give her best. Self-confident, the hero tries to impress. She thinks big, she thinks ahead of her time, her dreams of glory drive her far away. She prefers dramatic actions 
to efficient ones. Of course, if she can do both, she will. Nonetheless, she has her priorities. The hero entrepreneur is the one who exists in the eye of the beholder. At any price, she wants to distinguish herself. To exist is to differ, to stand out from the masses. Her pride can take her to the summit or shoot her down. She does not readily look back. Therefore, she does not often succumb to sadness or regret. Like Schumpeter's entrepreneur, the hero seeks success for the sake of success. She relishes conquering, proving herself superior to others. Ventures are full of delight for her. Risk-neutral, she is not characterized by a higher education.

For the hero entrepreneur, uncertainty is neither a threat nor an opportunity: a chance to prove her bravery. Thus, she won't try to reduce uncertainty. She trusts her instincts and is on the lookout for her competitors' strategy, guessing their next move so as to better thwart their schemes. A natural-born leader, the hero entrepreneur is sensitive to the competence of her staff. Two circumstances seem to have a special grip on her: an increase in sales revenues and an expansion of the market. The former is indicative of her present success, the latter of her future success.

\section{The Mogul}

Above all, she relishes luxury and expenses. The mogul entrepreneur expects to live voluptuously a life of delights. Pleasure is her vocation, enjoyment her driving force. Her company is the great theatre of her person. The mogul entrepreneur gets drunk on herself; she expects her employees to present a mirror where she could be reflected. She has delusions of grandeur. Interestingly, she works for bigger companies than the others. The sweetest music is the one of eulogy. This hot-headed temperament is looking for seduction. Jealous of her prerogatives, she wants to acquire a respected social status and lead. She does not undertake a business out of love for the job, but out of love of money - for the delights it enables.

She gets informed and relies on the forecasts of experts. More often than for her counterparts, the prospect of a decline is unbearable. Then, she feels imperiled in her status and life of delights. Therefore, she will invest more to evade such awkward situations. Since she often 
goes on a spending spree, she is less prone to be deterred by questions of finance. Once she is convinced, she will invest, at any price.

\section{The Prophet}

The prophet entrepreneur is a visionary. Her speeches resemble preaches. Future is just here, so close. She sees it, she is about to seize it. She intends to change the world, to make it a better place, at least for her customers. A creative person, unlike the inventor, she does not need to experiment new ideas relentlessly. She has a purpose. The prophet entrepreneur grasps key elements of market trends and society metamorphoses; she feels them in her guts. This inspired individual is future's agent. She goes where others step back. She has many traits of a schumpeterian entrepreneur: the "will to conquer", take up challenges and "found a private kingdom", the "joy of creating", because "there is nothing else she can do". Unlike the inventor or innovator, she has an eye for detail, enabling her to turn new ideas or inventions into economic forms or processes.

Even if she is risk-neutral, she lives in fear that all the beautiful constructions of her mind may collapse. Highly educated, she keeps herself informed of all technological, scientific and social evolutions. Her curiosity is unquenchable. Of all her counterparts, the prophet entrepreneur thinks the most in terms of expected returns. Often, she invests with a view to launching new products or services. She is very intent on pursuing her ideas, devising new projects in order to complement or tackle the loopholes of older ones, which implies that she may somehow be susceptible to escalation of commitments. As regards the power of circumstances, she seems bound to respond vigorously to adversity, meaning that she will invest more than her counterparts in situations of fall in profits, sales revenues and market shares.

\section{The Craftsman}

The craftsman entrepreneur does not seek affluence at any price. She may lack creativity and self-confidence, but she loves her job and takes great care of her products. Values seem more important than easy money. She is an "old-times" entrepreneur favoring quality of service over 
profitability and probability calculus... What matters to her is to follow through her ideas and schemes - and satisfy the customer. The craftsman is wary of the uncontrolled flights of fancy and enthusiasm. Growth is considered with suspicion: bankruptcy can happen so quickly... In this regard, she is close to the paternalistic manager. She differs by a weak self-confidence, less control of her emotions, less ruminations and second thoughts, more education... Like her, she under-invests. More than anyone else, she needs stable foundations and safe guarantees to undertake any investment project.

\section{The Inventor}

Rumor has it this entrepreneur is weird, fickle, dreamy, lost in the clouds. From an outside perspective, her trajectory may appear unstable, chaotic. Conventional minds may judge her severely, and yet she is ahead of many ideas. Some of them are dead-ends, some show great potential. Any time an idea crosses her mind, she needs to experiment it. Technical issues may occupy her mind days and nights. She may lose sleep and appetite, health and wealth. Innovation is a vital necessity for her. She performs tests in her lab or plunges in her thoughts any time inspiration seizes her. Of the dozens of projects she embarks on, very few end in anywhere. This optimistic character would risk everything on a single idea. To solve riddles and meet unmet needs is one of her greatest joys. She values creativity more than anything else; novel technologies, bold ideas enthrall her.

The inventor entrepreneur readily places herself at the cutting edge of innovation. Therefore, she is on the lookout for her competitors' moves and she tries to stand out from them. First of all, because innovating implies not to copy and to spot unmet needs and technical loopholes, next because old ideas can give birth to novel ones: the more you multiply the opportunities to make them meet, the better for creativity. One circumstance in particular entices her to invest: market expansion. A fall in sales revenues and profits seems to exert a deterrent effect. Such is also the case with possibilities of financing, since the inventor entrepreneur risks it all while pursuing her ideas. 


\section{The Gambler}

The gambler has one thrill: risk. Not only does she value it for itself, but she appreciates it uncontrollable. This connoisseur of thrills would sacrifice everything to them. She could stake everything - wealth, reputation, career - on a single investment. Uncertainty is her ally: in troubled times, when the ground of established wisdom seems to shirk, she does not see doubts and contradictions as deterrents. According to her, these times are full of opportunities, waiting to be seized. She is the entrepreneur of lightning rises and dramatic falls. When she knows success, she won't be content for long. The siren call for risk will lure her again. This highlyeducated, optimistic entrepreneur does not believe management to be a practical matter; she considers it like a mix of board game and riddle. Despair is but a word. She is an entrepreneur of challenges. She relishes walking on the tightrope of business, feeling the dizziness of danger.

She feels the market - and follows her intuitions. When needed, she may even create it. As a risk-all individual, she is more prone to invest - by far - than her counterparts in difficult times such as a fall in profits, sales revenues and market shares.

\section{The Explorer}

She is the "conquistador of the impossible". Always on the move, she is made for the toughest struggles. Of all entrepreneurs, she is the one who relies the most on her instincts. This passionate, inflexible nature is subject to upsurges of devastating anger. Whimsical, impulsive, she is obsessed days and nights by her projects. She knows no fear and does not step back in front of quips, tribulations and rebukes. Creative, she goes to the utmost end of her ideas. At all costs. Her motivations have nothing to do with love of money or social status: she loves to explore new paths, test untried ideas. Her management style is innovative, not technical. Any time a project has fulfilled its potentialities, the explorer needs to embark upon a new activity. Relentlessly, she intends to push back her limits. She could undertake a project merely to prove herself. She takes all risks: entrepreneurship is a life style, an overflow of energy, an outlet for 
her pulses. A never-ending quest. That's why this athlete of the will does not believe in the utility of profitability and probability calculus: if the project is sound, profits are bound to come. Too precise a provisional planning is but smoke and mirrors.

The explorer does not care about reducing uncertainty. Given her impulsive and hot-tempered nature, she is bound to respond vigorously to threatening circumstances, such as a fall in profits, sales and market shares. Therefore, comparatively to her counterparts, she will less balk at investing. The following tables will enable a cross-comparison of our 11 groups of entrepreneurs on the basis of the classification, independent variables and the dependent variables.

\section{Insert Tables 14 and 15 here}

\section{Discussion and conclusion}

The analysis showed that we could obtain 11 stable groupings of entrepreneurs with regard to investment expectations, which is arguably the subject matter in which entrepreneurs are the most heterogeneous - since there is so little basis for rational calculations - and in which such heterogeneity has the greatest influence. We clustered entrepreneurs assuming that $d$ would revolve around 0.5. Most of the time, when a variable was found to exert a significant influence, its $d$ was even above that value.

Next, if we look only at the independent variables, we see that some of them are more important in that they appear statistically significant for a higher number of groups. Creativity and risk-taking propensity appear the most important traits, while "to gain social status and lead", "valuation of money" and "to gain independence and autonomy" seem, on the whole, to be the most important motivations. Please remind we are talking about variance of our data. Thus, we are merely saying here that, overall, these variables were the most frequently used in our classification. Still, we should bear in mind that albeit some classification variables were less frequently used, they could play some role in the constitution of one or more groups. For instance, impulsivity was not determinant for the constitution of 10 groups, but was of 
paramount importance for the "explorer" group (the fact of belonging to this group accounted for $43.52 \%$ of this variable's variance among its members).

Since our dependent variables also significantly differ from one group to another, we may conclude that we obtained specific patterns of investment expectations. Some entrepreneurs appear more sensitive than their counterparts to contexts of crises, while others comparatively over-invest in favorable circumstances. Their behavior also seems to vary across groups: some try to perform precise calculations, while others rely on their gut feelings or innovate at any price.

\subsection{Limitations}

This study is limited in its sample size. Even if our effect sizes for each group appeared relatively important, we should bear in mind that we dealt with small groups of at least 20 entrepreneurs as compared to a general sample of 289 entrepreneurs. Furthermore, one may question the universality of our study, since we only surveyed 1) French entrepreneurs, 2) entrepreneurs from two specific industries. While studying entrepreneurs from the same sector enables to control for any potential effect exerted by varying sectors, it is clearly a limitation, since the contexts and habits of such specific industries may entice entrepreneurs to behave differently from the rest of the general population of entrepreneurs. Besides, although motivations to run a business appear universal, their significance or causal role may differ from country to country.

Another issue that remains open is the temporal stability of our taxonomy. Will it change over time? What is the interplay between traits and age? Put differently: do group members evolve over time so that their traits change and make them switch groups? These questions are all the more vital as we have shown that the group of paternalistic managers stands out in terms of experience. Of course, like any other classification, ours is strongly dependent on the variables retained. Should some of them appear irrelevant or questionable, doubts would have been cast on our taxonomy. Even though we strived to incorporate most findings from past research, some variables 1) may have escaped our notice 2) may be too crude for an appropriate assessment. 
For example, we believe skills go beyond education and experience, no matter how crucial these two variables may be. Yet, we are limited by our method of collecting data.

\subsection{Directions of future research}

To overcome some of these limitations, we may perform another survey in another country and include more sectors. We may also try to replicate this study in the same country for entrepreneurs from other sectors. Indeed, if this taxonomy is stable, we should obtain a similar classification with the same method. The key issue of the stability of our taxonomy is an empirical question that ought to be answered accordingly. Future research should also try to increase sample sizes.

Furthermore, we may also want to test our taxonomy with regard to other types of expectations, namely production, speculation, etc. For instance, do "explorers" behave like "gamblers" in matters of speculation? If not, what would it mean for our taxonomy? We could still find consistent patterns. For example, if a future empirical study outlines six types of speculative behaviors (as dependent variables), it could be the case that by merging some of our 11 groups we obtain similar clustering of independent variables. Thus, "explorers" and "gamblers", say, would behave similarly when it comes to speculation, but differently when it comes to productive investment.

\subsection{Conclusion}

Finally, we believe that this study may represent an important and meaningful step toward clarifying the role of entrepreneurs' heterogeneity as to investment expectations. To the best of our knowledge, affect is incorporated into a taxonomy of entrepreneurs for the first time. Not only are animal spirits empirically assessed, but we obtain 11 groups of entrepreneurs, pertaining to 11 different animal spirits. Our findings highlight that entrepreneurs do behave differently and do not respond to the same type of circumstances. Thus, we hope to have offered a sharp picture of this fascinating concept called "animal spirits". 


\section{References}

AKERlof George, Robert SHILler, 2009, Animal Spirits, Princeton: Princeton University Press. Arora Punit, Michael Haynie, Gregory Laurence, 2013, "Counterfactual Thinking and Entrepreneurial Self-Efficacy: The Moderating Role of Self-Esteem and Dispositional Affect", Entrepreneurship: Theory and Practice, 37(2): 359-385.

BARON Robert, 2008, "The role of affect in the entrepreneurial process". Academy of Management Review, 33 (2): 328-40.

BARON Robert, Jintong TANG, Keith HMIElESKI, 2011, “The Downside of Being 'up': Entrepreneurs' Dispositional Positive Affect and Firm Performance". Strategic Entrepreneurship Journal, 5 (2): 101-119.

BARON Robert, Keith HMIELESKI, Rebecca HENRY, 2012, "Entrepreneurs' Dispositional Positive Affect: The Potential Benefits - and Potential Costs - of Being "up"'. Journal of Business Venturing, 27 (3): 310-324.

BAUM Robert, Edwin LOCKE, 2004, "The Relationship of Entrepreneurial Traits, Skill, and Motivation to Subsequent Venture Growth", Journal of Applied Psychology, 89 (4): 587-598.

BAUMOL William, 1968, "Entrepreneurship in Economic Theory", American Economic Review, 58 (2): 64-71.

Bazerman Max, Don Moore, 2009, Judgment in Managerial Decision Making. Hoboken: John Wiley \& Sons.

Bechara Antoine, Antonio DAmasio, 2005, “The Somatic Marker Hypothesis: A Neural Theory of Economic Decision", Games and Economic Behavior, 52 (2): 336-372.

Bechara Antoine, Hanna Damasio, Antonio Damasio, 2000, "Emotion, Decision Making and the Orbitofrontal cortex", Cerebral Cortex, 10: 295-307.

BEGLEY Thomas, David BOYD, 1987, "Psychological characteristics associated with performance in entrepreneurial firms and smaller businesses", Journal of Business Venturing, 2(1): 79-93.

Berthoz Alain, 2013, La Décision, Paris : Odile Jacob.

BERTRAND Marianne, Antoinette SchOAR, 2003, "Managing with Style: The Effect of Managers on Firm Policies", The Quarterly Journal of Economics, 68(4).

BrockHAus Robert, 1982, “The Psychology of the Entrepreneur", in C.A. Kent, D.L. Sexton, K.H. Vesper (eds), Encyclopedia of Entrepreneurship, Englewood-Cliffs: Prentice-Hall.

BusENITZ Lowell, 1999, "Entrepreneurial Risk and Strategic Decision Making”, The Journal of Applied Behavioral Science, 35 (3): 325-340.

CAMERER Colin, Martin WeBer, 1992, "Recent Developments in Modeling Preferences", Journal of Risk and Uncertainty, 5 (4) : 325-370.

CAPlin Andrew, Mark Dean, 2008, "Dopamine, Reward Prediction Error and Economics", Quarterly Journal of Economics, 123 (2): 663-701.

CARABElli Anna, 1988, On Keynes's Method. London: MacMillan.

CASSON Mark, 2000, "An entrepreneurial theory of the firm". Competence, Governance and Entrepreneurship: Advances in Economic Strategy Research, 116-45.

CASSON Mark, 2005, "Entrepreneurship and the theory of the firm". Journal of Economic Behavior \& Organization, 58 (2): 327-48. 
CASson Mark, Andrew Godley, 2005, "Entrepreneurship and Historical Explanation", in Cassis Youssef, Ionna Pepelasis Minoglou (eds.), Entrepreneurship in Theory and History, London: Palgrave McMillan.

Chandler Gaylen, Dawn DeTienne, Alexander McKelvie, Troy Mumford, 2011, "Causation and Effectuation Processes: A Validation Study". Journal of Business Venturing, 26(3): 375-390.

CHELl Elizabeth, 2008, The Entrepreneurial Personality: A Social Construction, London: Routledge. CoOPER Arnold, Carolyn WoO, William Dunkelberg, 1988, "Entrepreneurs' Perceived Chances for Success", Journal of Business Venturing, 3 (2): 97-108.

DAlgleish Tim, Mick Power, 2008, Cognition and Emotion, Hove: Psychology Press.

DAMASIO Antonio, 1994, Descartes' Error: Emotion, Feeling and the Human Brain. New York: Putnam Publishing.

DAMASIO Antonio, 2003, Looking for Spinoza: Joy, Sorrow, and the Feeling Brain. New York: Harcourt.

DAMASIO Antonio, 2009, "Neuroscience and the Emergence of Neuroeconomics", Glimcher, P. \& al. (eds.), Neuroeconomics: Decision Making and the Brain, Amsterdam: Elsevier.

Damasio Antonio, 2010, Self Comes to Mind: Constructing the Conscious Brain. New York: Pantheon Books.

DAVIDSON Paul, 1991, "Is Probability Theory Relevant for Uncertainty? A Post-Keynesian Perspective", Journal of Economic Perspectives, 5 (1): 129-143.

DAVIDSON Paul, 1996, "Reality and economic theory", Journal of Post Keynesian Economics, 18 (4): 479-508.

DAVIDSSON Per, 1995, "Determinants of Entrepreneurial Intentions", Rent IX Workshop, Piacenza, 23-24 novembre.

DAVIDSSON Per, 2005, "Methodological approaches to entrepreneurship: Past research and suggestions for the future". Small Enterprise Research, 13 (1): 1-21.

DAVIDSSON Per, 2007, "Dealing with Heterogeneity in Entrepreneurship Research", 4th AGSE International Entrepreneurship Research Exchange 2007, 6 - 9 February, Brisbane, Australia. Debreu Gérard, 1983, Théorie de la Valeur, Paris : Dunod.

DellaVigna Stefano, 2009, "Psychology and Economics: Evidence from the Field". Journal of Economic Literature, 47 (2): 315-372.

DoIDGE Norman, 2007, The Brain that Changes Itself, London: Penguin.

Dow Alexander, Sheila Dow, 2011, “Animal Spirits Revisited”. Capitalism and Society, 6 (2): $1-23$.

EARL Peter, 2005, "Economics and Psychology in the Twenty-First Century", Cambridge Journal of Economics, 29 (6): 909-926.

ELSTER Jon, 1998, “Emotions and Economic Theory", Journal of Economic Literature, 36(1): 47-74.

FILION Louis-Jacques, 2000, “Entrepreneurial Typologies: Are They Really Useful?”, in

Brauchlin E., Pichler, J.H. (Eds), Unternehmer und Unternehmens-perspektiven für Klein- und Mittelunternehmen, Berlin: Duncker \& Humbolt.

FILley Alan, Ramon AldAG, 1978, "Characteristics and Measurement of an Organizational Typology”, Academy of Management Journal, 21(4): 578-591.

Foss Kirsten, Nicolai Foss, Peter Klein and Sandra Klein, 2007, "The Entrepreneurial Organization of Heterogeneous Capital”, Journal of Management Studies, 44:7. 
Foo Maw-Der, 2011, "Emotions and Entrepreneurial Opportunity Evaluation". Entrepreneurship Theory and Practice, 35 (2): 375-393.

Foo Maw-Der, Marilyn Uy, Charles MurnIEKS, 2013, "Beyond Affective Valence: Untangling Valence and Activation Influences on Opportunity Identification". Entrepreneurship Theory and Practice, online (no issue yet).

GARTNER William, 1989, "Who is an Entrepreneur? is the Wrong Question", Entrepreneurship: Theory and Practice, 13 (4): 47-67.

GLIMCHER Paul, 2009, "Choice: Towards a Standard Back-Pocket Model”, Glimcher Paul et al. (eds.), Neuroeconomics: Decision Making and the Brain, Amsterdam: Elsevier.

GLIMCHER Paul, 2011a, Foundations of Neuroeconomic Analysis, Oxford: Oxford University Press.

GLIMCHER Paul, 2011b, "Understanding Dopamine and Reinforcement Learning: The Dopamine Reward Prediction Error Hypothesis", Proceedings of the Natural Science Academy, 108 (3): 15647-15654.

GRICHNIK Dietmar, Alexander SMEJA, Isabell WelPE, 2010, "The Importance of Being Emotional: How Do Emotions Affect Entrepreneurial Opportunity Evaluation and Exploitation?" Journal of Economic Behavior \& Organization, 76 (1): 15-29.

HANOCH Yaniv, 2002, "Neither an Angel, nor an Ant: Emotions as an Aid to Bounded Rationality", Journal of Economic Psychology, 23 (1): 1-25.

Hayton James, Magdalena Cholakova, 2012, "The Role of Affect in the Creation and Intentional Pursuit of Entrepreneurial Ideas". Entrepreneurship Theory and Practice, 36 (1): 41-68. HENNIG Christian, 2007, "Cluster-wise assessment of cluster stability". Computational Statistics and Data Analysis, 52, 258-271.

HMIELESKI Keith, Robert BARON, 2008, "When Does Entrepreneurial Self-Efficacy Enhance versus Reduce Firm Performance?” Strategic Entrepreneurship Journal, 2 (1): 57-72.

HMIELSKI Keith, Robert BARON, 2009, 'Entrepreneurs' optimism and new venture performance: A social cognitive perspective". Academy of management Journal, 52 (3): 473-88.

Hogarth Robin, Natalia Karaleia, 2012, "Entrepreneurial Success and Failure: Confidence and Fallible Judgment”, Organization Science, 23 (6): 1733-1747.

JOHNSON Bradley, 1990, "Towards a Multi-Dimensional Model of Entrepreneurship: the Case of Achievement Motivation and the Entrepreneur", Entrepreneurship: Theory and Practice, 14(3): 39-54.

KAUFMAN Bruce, 1999, "Emotional arousal as a source of bounded rationality". Journal of Economic Behavior \& Organization, 38 (2): 135-44.

Keltner Dasher, Jennifer LeRner, 2010, "Emotions", in Susan Fiske, Daniel Gilbert, Gardner Lindzey (eds.), Handbook of Social Psychology, vol 1, Hoboken: John Wiley and sons.

KEYNES John Maynard, 1936, The General Theory of Employment, Interest and Money, London: McMillan.

KEYNES John Maynard, 1937, “The General Theory of Employment”, Quarterly Journal of Economics, 51(2): 209-223.

KIRZNER Israel, 1979, Perception, Opportunity and Profit: Studies in the Theory of Entrepreneurship, Chicago: University of Chicago Press.

KNIGHT Frank, 1921, Risk, Uncertainty and Profit, New York: Harper.

Kobayashi Shunsuke, Wolfram SchUltz, 2008, "Influence of Reward Delays on Responses of Dopamine Neurons", Journal of Neuroscience, 28, 7837-7846 
Koenigs Michael, Ralph AdolPhs, 2009, "Emotion and Consciousness", in Gazzaniga Michael (ed.), The Cognitive Neurosciences, fourth edition, Cambridge: MIT Press.

KRUEGER Jr Norris, Peter DiCKSON, 1994, "How Believing in Ourselves Increases Risk-Taking: Perceived Self-Efficacy and Opportunity Recognition”, Decision Sciences, 25 (3): 385-400.

LAFUENTE Alberto, Vicente SALAS, 1989, "Types of Entrepreneurs and Firms: The Case of New Spanish Firms", Strategic Management Journal, 10: 17-30.

LeDoux Joseph, 2002, Synaptic Self. London: Penguin.

LERNER Jennifer, Keltner DASHER, 2001, "Fear, Anger, and Risk", Journal of Personality and Social Psychology, 81 (1): 146-159.

LOOMES Graham, Robert Sugden, 1987, "Some Implications of a More General Form of Regret Theory", Journal of Economic Theory, 41 (2): 270-287.

MARCH James, Zur SHAPIRA, 1987, "Managerial perspectives on risk and risk taking". Management science, 33 (11): 1404-18.

MARCH James, Zur SHAPIRA, 1992, "Variable Risk Preferences and the Focus of Attention", Psychological Review, 99 (1): 172-183.

MarchiOnatTi Roberto 1999, “On Keynes's Animal Spirits”, Kyklos, 52, no.3.

MetCALfe Stanley, 2006, "Entrepreneurship: An Evolutionary Perspective", in Casson Mark, Nigel Wadeson, Bernard Yeung (eds.), The Oxford Handbook of Entrepreneurship, Oxford: Oxford University Press.

Mischel Walter, 2004, "Toward an Integrative Science of the Person", Annual Review of Psychology, 55: 1-22.

Mischel Walter, Yuichi SHODA, 1995, "A cognitive-affective system theory of personality: reconceptualizing situations, dispositions, dynamics, and invariance in personality structure", Psychological Review, 102: 246-268.

Mitchell Ronald, Lowell Busenitz, Barbara BIRD, Connie Marie Gaglio, Jeffery McMullen, Eric Morse, Brock SMITH, 2007, "The central question in entrepreneurial cognition research 2007'. Entrepreneurship Theory and Practice, 31 (1): 1-27.

Morris Michael, Donald KuratKo, Minet SchindehutTe, April SpIVAcK, 2012, "Framing the Entrepreneurial Experience", Entrepreneurship: Theory and Practice, 36(1): 11-40.

MurAmATSU Roberta, Yaniv HANOCH, 2005, "Emotions as a Mechanism for Boundedly Rational Agents: The Fast and Frugal Way”. Journal of Economic Psychology, 26 (2): 201-221.

Nussbaum Martha, 2001, Upheavals of Thought, Cambridge: Cambridge University Press.

O'Donnell Roderick, 1990, “The Epistemology of JM Keynes”. The British Journal for the Philosophy of Science, 41 (3): 333-50.

PHELPS Elizabeth, 2009, "Emotion and Decision Making", in Gazzaniga Michael (ed.), The Cognitive Neurosciences, fourth edition, Cambridge: MIT Press.

Podoynitsyna Ksenia, Hans VAn Der BiJ, Michael Song, 2012, "The Role of Mixed Emotions in the Risk Perception of Novice and Serial Entrepreneurs", Entrepreneurship: Theory and Practice, 36(1): 115-140.

Robinson Peter, David StimPSOn, Jonathan HuEFnER, Keith HunT, 1991, “An Attitude Approach to the Prediction of Entrepreneurship", Entrepreneurship: Theory and Practice, 15(4): 13-31.

SARASVATHY Saras, 2001, "Causation and effectuation: Toward a theoretical shift from economic inevitability to entrepreneurial contingency". Academy of Management Review, 26(2): 243-63. 
SARASVATHY Saras, Sankaran VenKataraman, 2011, "Entrepreneurship as Method: Open Questions for an Entrepreneurial Future". Entrepreneurship: Theory and Practice, 35(1): 113-135. Schultz Wolfram, 2009, "Midbrain Dopamine Neurons: A Retina of the Reward System?", Glimcher Paul \& al. (eds.), Neuroeconomics: Decision Making and the Brain, Amsterdam: Elsevier. Schultz Wolfram , Peter Dayan, Read Montague, 1997, “A Neural Substrate of Prediction and Reward", Science, 275: 1593-1599

SCHUMPETER Joseph, 1934, The Theory of Economic Development, Cambridge: Harvard Series.

SCHWARZ Norbert, 2002, "Feelings as Informations: Moods Influence Judgments and Processing Strategies." in Gilovitch Thomas, Dale Griffin, Daniel Kahneman (eds.), Heuristics and Biases, Cambridge: Cambridge University Press.

SCHWARZ Norbert, Gerald CLORE, 2003, "Mood as information: 20 years later". Psychological Inquiry, 14 (3-4): 296-303.

STAUfER William, Armin LaK, Wolfram Schultz, 2014, "Dopamine: Reward Prediction Error Responses Reflect Marginal Utility”, Current Biology, 24: 2491-2500.

SHACKLE George, 1955, Uncertainty in Economics, and other Reflections. Cambridge: Cambridge University Press.

SHACKLE George, 1967, The Years of High Theory: Invention and Tradition in Economic Thought, Cambridge: Cambridge University Press.

Shane Scott, Sankaran Venkataraman, 2000, "The Promise of Enterpreneurship as a Field of Research", The Academy of Management Review, 25 (1): 217-226.

Shane Scott, Edwin Locke, Christopher Collins, 2003, "Entrepreneurial Motivation", Human Resource Management Review, 13: 257-279

SIMON Herbert, 1955, “A Behavioral Model of Choice”, The Quarterly Journal of Economics, 69 (1): 99-118.

SIMON Herbert, 1956, "Rational Choice and the Structure of the Environment", Psychological Review, 63 (2): 129-138.

SIMON Herbert, 1959, "Theories of Decision-Making in Economics and Behavioral Science", The American Economic Review, 49 (3): 253-283.

SIMON Herbert, 1965, “The Logic of Rational Decision”, British Journal for the Philosophy of Science, 16: 169-186.

SimON Herbert, 1979, "Rational Decision Making in Business Organizations", American Economic Review, 69 (4): 493-513.

SIMON Herbert, 1990, “Invariants of Human Behavior". Annual Review of Psychology, 41: 1-19.

SMITH Norman, John Miner, 1983, "Type of Entrepreneur, Type of Firm, and Managerial Motivation: Implications for Organizational Life Cycle Theory", Strategic Management Journal, 4: 325-340.

STEWART Wayne, Philip Roth, 2001, "Risk-taking propensities - Entrepreneurs vs. Managers", Journal of Applied Psychology, 86 (1): 145-153.

TANG Jintong, Zhi TANG, Franz LOHRKE, 2008, "Developing an Entrepreneurial Typology: The Roles of Entrepreneurial Alertness and Attributional Style", International Entrepreneurship and Management Journal, 4(3): 273-294.

TREPEL Christopher, Craig Fox, Russell POLDRACK, 2005, "Prospect Theory on the Brain? Toward a Cognitive Neuroscience of Decision Under Risk", Cognitive Brain Research, 23: 34-50. 
WADESON Nigel, 2006, "Cognitive Aspects of Entrepreneurship: Decision-Making and Attitudes to Risk". in Casson Mark, Nigel Wadeson, Bernard Yeung (eds.), The Oxford Handbook of Entrepreneurship, Oxford: Oxford University Press.

WALras Léon, 1888 (1988), Eléments d'économie politique pure, Paris : Economica.

WEBER Max, 1957, Essays in Sociology, London : Routledge.

WelPE Isabell, Matthias SPÖRRLE, Dietmar GRICHNIK, Theresa MiCHL, David AudRETSCH, 2012, "Emotions and Opportunities: The Interplay of Opportunity Evaluation, Fear, Joy, and Anger as Antecedent of Entrepreneurial Exploitation". Entrepreneurship Theory and Practice, 36(1): 69-96.

Woo Carolyn, Arnold Cooper, William Dunkelberg, 1991, "The Development and Interpretation of Entrepreneurial Typologies", Journal of Business Venturing, 6(6): 93-114.

Zahra Shaker, Eric Gedajlovic, Donald Neubaum, Joel Shulman, 2009, “A Typology of Social Entrepreneurs: Motives, Search Processes and Ethical Challenges", Journal of Business Venturing, 24: 519-532.

ZAJONC Robert, 1998, "Emotions", in Gilbert Daniel, Susan Fiske, Gardner Lindzey (eds.), Handbook of Social Psychology, New York: Oxford University Press. 
Appendix

Insert tables 3 to 13 
Tables

\begin{tabular}{|c|c|c|c|}
\hline & Variable & Type & Scale \\
\hline \multirow{10}{*}{ Motivations } & self-realization & \multirow{10}{*}{ Independent } & \multirow{10}{*}{3} \\
\hline & independence and autonomy & & \\
\hline & $\begin{array}{l}\text { transform society, share and defend your } \\
\text { vision, your project }\end{array}$ & & \\
\hline & explore and innovate & & \\
\hline & impress and reach glory & & \\
\hline & take up a challenge & & \\
\hline & found a durable, thriving company & & \\
\hline & out of love of the job and love of good work & & \\
\hline & social status and leadership & & \\
\hline & $\begin{array}{l}\text { make as much money as possible in order } \\
\text { to enjoy life at its fullest }\end{array}$ & & \\
\hline \multirow{3}{*}{ Skills } & $\begin{array}{l}\text { Education } \\
\end{array}$ & \multirow{3}{*}{ Independent } & 7 \\
\hline & Manager experience & & Up to 50 \\
\hline & Executive experience & & \\
\hline \multirow{3}{*}{ Management styles } & Pragmatic & \multirow{3}{*}{ Independent } & \multirow{3}{*}{3} \\
\hline & Technical & & \\
\hline & Innovative & & \\
\hline \multirow{10}{*}{ Traits } & Risk-taking propensity & \multirow{10}{*}{ Independent } & \multirow{10}{*}{5} \\
\hline & Attitude towards uncertainty & & \\
\hline & Optimism & & \\
\hline & Self-confidence & & \\
\hline & Impulsivity & & \\
\hline & Creativity & & \\
\hline & Joyfulness & & \\
\hline & Fearlessness & & \\
\hline & Tendency to feel regret & & \\
\hline & Crossness & & \\
\hline \multirow{9}{*}{ Investment behavior } & Precise calculus & \multirow{9}{*}{ Dependent } & \multirow{9}{*}{5} \\
\hline & Profit options & & \\
\hline & Experts' opinion & & \\
\hline & Re-examination as new data crops up & & \\
\hline & Edge of innovation & & \\
\hline & Gut feelings & & \\
\hline & Distinction & & \\
\hline & Create market & & \\
\hline & Uncertainty reduction (securing investment) & & \\
\hline
\end{tabular}




\begin{tabular}{|c|c|c|c|}
\hline & On the lookout & & \\
\hline & Priority to staff competence & & \\
\hline \multirow{14}{*}{ Investment contexts } & Rise in profits & \multirow{14}{*}{ Dependent } & \multirow{14}{*}{5} \\
\hline & Rise in sales revenues & & \\
\hline & Fall in interest rates & & \\
\hline & High level of self-financing & & \\
\hline & Signature of a new client/contract & & \\
\hline & Possibilities of financing & & \\
\hline & Experts' forecasts & & \\
\hline & Lesser yield of alternative investments & & \\
\hline & Shareholders' demands & & \\
\hline & Market expansion & & \\
\hline & Fall in profits & & \\
\hline & Fall in sales revenues & & \\
\hline & Fall in market shares & & \\
\hline & Cost increase & & \\
\hline
\end{tabular}

Table 1. Variables of our study

\begin{tabular}{|c|c|c|c|c|c|}
\hline Mogul & Neoclassical entrepreneur & Inventor & Craftsman & Builder & Gambler \\
\hline 1,000 & 1,000 & 1,000 & 0,967 & 0,933 & 0,917 \\
\hline Administrator & Paternalistic manager & Hero & Explorer & \multicolumn{2}{|c|}{ Prophet } \\
\hline 0,883 & 0,867 & 0,833 & 0,817 & 0,767 \\
\hline
\end{tabular}

Table 2. Jaccard indices between our two clusterings

\begin{tabular}{|l|c|c|c|c|c|}
\hline Significant Variable & Fearlessness & $\begin{array}{c}\text { Attitude towards } \\
\text { uncertainty }\end{array}$ & $\begin{array}{c}\text { Behavior: } \\
\text { Experts forecast }\end{array}$ & $\begin{array}{c}\text { Behavior: } \\
\text { precise calculus }\end{array}$ & $\begin{array}{c}\text { Behavior: } \\
\text { profit options }\end{array}$ \\
\hline General Mean & 3,88 & 1,80 & 1,74 & 1,99 & 1,81 \\
\hline General sdeviation & 0,77 & 0,65 & 0,88 & 1,02 & 1,04 \\
\hline Group Mean & 4,40 & 1,40 & 2,11 & 3,11 & 2,42 \\
\hline Group sdeviation & 0,75 & 0,50 & 0,66 & 0,76 & 0,90 \\
\hline $\boldsymbol{t}$ & 2,925 & $-2,696$ & 1,822 & 4,830 & 2,500 \\
\hline $\boldsymbol{d}$ & 0,676 & $-0,623$ & 0,421 & 1,117 & 0,592 \\
\hline Variance explained & $33,37 \%$ & $40,00 \%$ & $25,52 \%$ & $72,00 \%$ & $32,65 \%$ \\
\hline
\end{tabular}

\begin{tabular}{|l|c|c|c|c|c|}
\hline $\begin{array}{l}\text { Significant } \\
\text { Variable }\end{array}$ & $\begin{array}{c}\text { Behavior: } \\
\text { reexamination }\end{array}$ & $\begin{array}{c}\text { Circumstances: } \\
\text { fall interest rate }\end{array}$ & $\begin{array}{c}\text { Circumstances: } \\
\text { alternative yield }\end{array}$ & $\begin{array}{c}\text { Circumstances: } \\
\text { shareholders }\end{array}$ & $\begin{array}{c}\text { Circumstances: } \\
\text { rising profits }\end{array}$ \\
\hline General Mean & 1,91 & 1,656 & 0,809 & 0,618 & 2,109 \\
\hline General sdeviation & 0,98 & 1,039 & 0,967 & 0,912 & 1,140 \\
\hline Group Mean & 2,45 & 2,21 & 1,63 & 1,16 & 2,61 \\
\hline Group sdeviation & 0,76 & 0,98 & 0,83 & 0,90 & 0,70 \\
\hline $\boldsymbol{t}$ & 2,414 & 2,321 & 3,714 & 2,567 & 1,946 \\
\hline $\boldsymbol{d}$ & 0,558 & 0,536 & 0,859 & 0,593 & 0,450 \\
\hline
\end{tabular}




\begin{tabular}{|l|l|l|l|l|l|}
\hline Variance explained & $34,75 \%$ & $26,39 \%$ & $52,14 \%$ & $28,64 \%$ & $37,85 \%$ \\
\hline
\end{tabular}

Table 3. The Neoclassical Entrepreneur

\begin{tabular}{|l|c|c|c|c|c|}
\hline $\begin{array}{l}\text { Significant } \\
\text { Variable }\end{array}$ & Creativity & Risk-taking & $\begin{array}{c}\text { Motivation: } \\
\text { found empire }\end{array}$ & $\begin{array}{c}\text { Motivation: } \\
\text { innovate }\end{array}$ & $\begin{array}{c}\text { Motivation: } \\
\text { challenges }\end{array}$ \\
\hline General Mean & 3,74 & 4,35 & 1,69 & 0,62 & 1,13 \\
\hline General sdeviation & 0,84 & 1,27 & 1,25 & 1,05 & 1,25 \\
\hline Group Mean & 3,27 & 3,67 & 2,19 & 0,15 & 0,62 \\
\hline Group sdeviation & 0,96 & 1,16 & 0,75 & 0,46 & 1,13 \\
\hline $\boldsymbol{t}$ & $-2,705$ & $-2,622$ & 2,015 & $-2,242$ & $-2,026$ \\
\hline $\boldsymbol{d}$ & $-0,554$ & $-0,535$ & 0,412 & $-0,459$ & $-0,415$ \\
\hline Variance explained & $25,16 \%$ & $26,25 \%$ & $31,85 \%$ & $51,20 \%$ & $17,64 \%$ \\
\hline
\end{tabular}

\begin{tabular}{|l|c|c|c|c|c|}
\hline $\begin{array}{l}\text { Significant } \\
\text { Variable }\end{array}$ & $\begin{array}{c}\text { Motivation: } \\
\text { job love }\end{array}$ & $\begin{array}{c}\text { Motivation: } \\
\text { Independence }\end{array}$ & $\begin{array}{c}\text { Technical } \\
\text { management }\end{array}$ & $\begin{array}{c}\text { Innovating } \\
\text { management }\end{array}$ & $\begin{array}{c}\text { Motivation: } \\
\text { self-realization }\end{array}$ \\
\hline General Mean & 1,78 & 1,29 & 1,95 & 1,85 & 0,58 \\
\hline General sdeviation & 1,27 & 1,30 & 0,81 & 0,81 & 1,01 \\
\hline Group Mean & 2,62 & 0,50 & 2,38 & 1,42 & 1,00 \\
\hline Group sdeviation & 0,57 & 0,81 & 0,64 & 0,58 & 1,17 \\
\hline $\boldsymbol{t}$ & 3,320 & $-3,043$ & 2,662 & $-2,627$ & 2,005 \\
\hline $\boldsymbol{d}$ & 0,680 & $-0,623$ & 0,545 & $-0,538$ & 0,410 \\
\hline Variance explained & $68,99 \%$ & $49,58 \%$ & $32,60 \%$ & $36,22 \%$ & $11,89 \%$ \\
\hline
\end{tabular}

\begin{tabular}{|l|c|c|c|c|}
\hline $\begin{array}{l}\text { Significant } \\
\text { Variable }\end{array}$ & $\begin{array}{c}\text { Behavior: } \\
\text { precise calculus }\end{array}$ & $\begin{array}{c}\text { Behavior: } \\
\text { competence }\end{array}$ & $\begin{array}{c}\text { Behavior: edge } \\
\text { of innovation }\end{array}$ & $\begin{array}{c}\text { Circumstances: } \\
\text { falling sales }\end{array}$ \\
\hline General Mean & 1,99 & 2,33 & 1,87 & 1,66 \\
\hline General sdeviation & 1,02 & 0,92 & 0,98 & 1,19 \\
\hline Group Mean & 2,38 & 2,81 & 1,38 & 2,19 \\
\hline Group sdeviation & 1,13 & 0,85 & 0,98 & 1,13 \\
\hline $\boldsymbol{t}$ & 1,873 & 2,552 & $-2,419$ & 2,194 \\
\hline $\boldsymbol{d}$ & 0,383 & 0,522 & $-0,495$ & 0,449 \\
\hline Variance explained & $11,18 \%$ & $24,75 \%$ & $20,23 \%$ & $18,70 \%$ \\
\hline
\end{tabular}

\begin{tabular}{|l|c|c|c|c|c|}
\hline Significant Variable & $\begin{array}{c}\text { Circumstances: } \\
\text { falling interest }\end{array}$ & $\begin{array}{c}\text { Circumstances: } \\
\text { self-financing }\end{array}$ & $\begin{array}{c}\text { Circumstances: } \\
\text { cost increase }\end{array}$ & $\begin{array}{c}\text { Circumstances: } \\
\text { rising sales }\end{array}$ & $\begin{array}{c}\text { Circumstances: } \\
\text { rising profits }\end{array}$ \\
\hline General Mean & 1,656 & 1,983 & 1,944 & 2,157 & 2,109 \\
\hline General sdeviation & 1,039 & 1,171 & 1,014 & 1,079 & 1,140 \\
\hline Group Mean & 2,24 & 2,44 & 2,46 & 2,62 & 2,73 \\
\hline Group sdeviation & 0,88 & 0,87 & 1,07 & 1,06 & 0,83 \\
\hline $\boldsymbol{t}$ & 2,781 & 1,943 & 2,483 & 2,078 & 2,716 \\
\hline $\boldsymbol{d}$ & 0,569 & 0,398 & 0,508 & 0,425 & 0,556 \\
\hline
\end{tabular}




\begin{tabular}{|c|c|c|c|c|c|}
\hline Variance explained & $32,33 \%$ & $23,02 \%$ & $19,66 \%$ & $16,25 \%$ & $37,00 \%$ \\
\hline \multicolumn{6}{|c|}{ Table 4. The Builder } \\
\hline $\begin{array}{l}\text { Significant } \\
\text { Variable }\end{array}$ & $\begin{array}{l}\text { Motivation: } \\
\text { money }\end{array}$ & $\begin{array}{l}\text { Motivation: } \\
\text { social status }\end{array}$ & $\begin{array}{l}\text { Motivation: } \\
\text { job love }\end{array}$ & $\begin{array}{l}\text { Motivation: } \\
\text { independence }\end{array}$ & $\begin{array}{l}\text { Risk-taking } \\
\text { propensity }\end{array}$ \\
\hline General Mean & 0,19 & 0,26 & 1,78 & 1,29 & 4,35 \\
\hline General sdeviation & 0,65 & 0,76 & 1,27 & 1,30 & 1,27 \\
\hline Group Mean & 0,58 & 0,00 & 2,46 & 2,27 & 3,81 \\
\hline Group sdeviation & 1,14 & 0,00 & 0,95 & 1,15 & 1,01 \\
\hline$t$ & 2,696 & $-1,742$ & 2,669 & 3,712 & $-2,117$ \\
\hline$d$ & 0,552 & $-0,357$ & 0,546 & 0,760 & $-0,433$ \\
\hline Variance explained & $10,74 \%$ & $100,00 \%$ & $34,97 \%$ & $42,95 \%$ & $23,04 \%$ \\
\hline
\end{tabular}

\begin{tabular}{|l|c|c|c|c|c|}
\hline Significant Variable & Education & $\begin{array}{c}\text { Behavior: uncertainty } \\
\text { reduction }\end{array}$ & $\begin{array}{c}\text { Behavior: } \\
\text { distinction }\end{array}$ & $\begin{array}{c}\text { Circumstances: } \\
\text { falling sales }\end{array}$ & $\begin{array}{c}\text { Circumstances: } \\
\text { falling profits }\end{array}$ \\
\hline General Mean & 3,65 & 0,90 & 2,74 & 1,660 & 1,608 \\
\hline General sdeviation & 1,60 & 1,18 & 0,93 & 1,190 & 1,155 \\
\hline Group Mean & 2,96 & 1,65 & 2,38 & 1,04 & 1,12 \\
\hline Group sdeviation & 1,18 & 1,41 & 0,90 & 1,00 & 1,03 \\
\hline $\boldsymbol{t}$ & $-2,324$ & 3,069 & $-1,872$ & $-2,582$ & $-2,100$ \\
\hline $\boldsymbol{d}$ & $-0,537$ & 0,628 & $-0,383$ & $-0,529$ & $-0,430$ \\
\hline Variance explained & $26,06 \%$ & $22,85 \%$ & $14,01 \%$ & $28,69 \%$ & $19,14 \%$ \\
\hline
\end{tabular}

\begin{tabular}{|l|c|c|c|c|c|}
\hline $\begin{array}{l}\text { Significant } \\
\text { Variable }\end{array}$ & $\begin{array}{c}\text { Circumstances: } \\
\text { falling shares }\end{array}$ & $\begin{array}{c}\text { Circumstances: } \\
\text { falling interest }\end{array}$ & $\begin{array}{c}\text { Circumstances: } \\
\text { self-financing }\end{array}$ & $\begin{array}{c}\text { Circumstances: } \\
\text { financing poss. }\end{array}$ & $\begin{array}{c}\text { Circumstances: } \\
\text { rising profits }\end{array}$ \\
\hline General Mean & 1,652 & 1,656 & 1,983 & 2,102 & 2,109 \\
\hline General sdeviation & 1,159 & 1,039 & 1,171 & 1,081 & 1,14 \\
\hline Group Mean & 1,08 & 2,15 & 2,54 & 2,62 & 2,69 \\
\hline Group sdeviation & 1,09 & 0,83 & 1,10 & 0,70 & 0,88 \\
\hline $\boldsymbol{t}$ & $-2,435$ & 2,375 & 2,328 & 2,376 & 2,540 \\
\hline $\boldsymbol{d}$ & $-0,498$ & 0,486 & 0,476 & 0,486 & 0,520 \\
\hline Variance explained & $22,37 \%$ & $27,04 \%$ & $20,85 \%$ & $36,05 \%$ & $31,17 \%$ \\
\hline
\end{tabular}

Table 5. The Administrator

\begin{tabular}{|l|c|c|c|c|c|}
\hline $\begin{array}{l}\text { Significant } \\
\text { Variable }\end{array}$ & Hot-Temper & $\begin{array}{c}\text { Risk-taking } \\
\text { propensity }\end{array}$ & $\begin{array}{c}\text { Motivation: } \\
\text { job love }\end{array}$ & $\begin{array}{c}\text { Experience as } \\
\text { executive }\end{array}$ \\
\hline General Mean & 2,39 & 4,35 & 1,78 & & 6,52 \\
\hline General sdeviation & 1,14 & 1,27 & 1,27 & & 7,45 \\
\hline Group Mean & 1,97 & 3,52 & 2,30 & & 3,40 \\
\hline Group sdeviation & 0,93 & 1,17 & 1,06 & & 6,11 \\
\hline $\boldsymbol{t}$ & $-1,967$ & $-3,446$ & 2,166 & & $-2,217$ \\
\hline
\end{tabular}




\begin{tabular}{|l|c|c|c|c|c|}
\hline $\boldsymbol{d}$ & $-0,377$ & $-0,661$ & 0,415 & & $-0,425$ \\
\hline Variance explained & $17,72 \%$ & $34,39 \%$ & $20,07 \%$ & & $21,24 \%$ \\
\hline
\end{tabular}

\begin{tabular}{|l|c|c|c|c|c|c|}
\hline $\begin{array}{l}\text { Significant } \\
\text { Variable }\end{array}$ & $\begin{array}{c}\text { Innovating } \\
\text { management }\end{array}$ & $\begin{array}{c}\text { Behavior: } \\
\text { uncertainty reduc. }\end{array}$ & $\begin{array}{c}\text { Behavior: } \\
\text { gut feelings }\end{array}$ & $\begin{array}{c}\text { Behavior: re- } \\
\text { examination }\end{array}$ & $\begin{array}{c}\text { Behavior: } \\
\text { competence }\end{array}$ & $\begin{array}{c}\text { Behavior: } \\
\text { distinction }\end{array}$ \\
\hline General Mean & 1,85 & 0,90 & 2,28 & 1,91 & 2,33 & 2,74 \\
\hline General sdeviation & 0,81 & 1,18 & 0,88 & 0,98 & 0,92 & 0,93 \\
\hline Group Mean & 1,50 & 1,33 & 1,86 & 1,40 & 1,97 & 2,37 \\
\hline Group sdeviation & 0,82 & 1,32 & 0,99 & 0,86 & 1,12 & 1,00 \\
\hline $\boldsymbol{t}$ & $-2,251$ & 1,893 & $-2,452$ & $-2,744$ & $-2,027$ & $-2,079$ \\
\hline $\boldsymbol{d}$ & $-0,432$ & 0,363 & $-0,470$ & $-0,526$ & $-0,389$ & $-0,399$ \\
\hline Variance explained & $15,86 \%$ & $10,01 \%$ & $16,03 \%$ & $26,90 \%$ & $10,23 \%$ & $12,61 \%$ \\
\hline
\end{tabular}

\begin{tabular}{|l|c|c|c|c|c|}
\hline $\begin{array}{l}\text { Significant } \\
\text { Variable }\end{array}$ & $\begin{array}{c}\text { Circumstances: } \\
\text { falling sales }\end{array}$ & $\begin{array}{c}\text { Circumstances: } \\
\text { falling profits }\end{array}$ & $\begin{array}{c}\text { Circumstances: } \\
\text { falling shares }\end{array}$ & $\begin{array}{c}\text { Circumstances: } \\
\text { falling interest }\end{array}$ & $\begin{array}{c}\text { Circumstances: } \\
\text { self-financing }\end{array}$ \\
\hline General Mean & 1,660 & 1,608 & 1,652 & 1,656 & 1,983 \\
\hline General sdeviation & 1,190 & 1,155 & 1,159 & 1,039 & 1,171 \\
\hline Group Mean & 1,13 & 1,10 & 1,00 & 1,17 & 1,50 \\
\hline Group sdeviation & 1,01 & 0,90 & 1,02 & 0,97 & 1,33 \\
\hline $\boldsymbol{t}$ & $-2,338$ & $-2,332$ & $-2,972$ & $-2,446$ & $-2,123$ \\
\hline $\boldsymbol{d}$ & $-0,448$ & $-0,445$ & $-0,570$ & $-0,469$ & $-0,407$ \\
\hline Variance explained & $22,02 \%$ & $25,18 \%$ & $31,29 \%$ & $21,16 \%$ & $11,96 \%$ \\
\hline
\end{tabular}

\begin{tabular}{|l|c|c|c|c|c|}
\hline $\begin{array}{l}\text { Significant } \\
\text { Variable }\end{array}$ & $\begin{array}{c}\text { Circumstances: } \\
\text { alternative yield }\end{array}$ & $\begin{array}{c}\text { Circumstances: } \\
\text { rising sales }\end{array}$ & $\begin{array}{c}\text { Circumstances: } \\
\text { rising profits }\end{array}$ & $\begin{array}{c}\text { Circumstances: } \\
\text { expansion }\end{array}$ & $\begin{array}{c}\text { Circumstances: } \\
\text { expert forecast }\end{array}$ \\
\hline General Mean & 0,809 & 2,157 & 2,109 & 2,458 & 0,683 \\
\hline General sdeviation & 0,967 & 1,079 & 1,140 & 1,017 & 0,920 \\
\hline Group Mean & 0,37 & 1,67 & 1,33 & 1,87 & 0,33 \\
\hline Group sdeviation & 0,67 & 1,15 & 1,21 & 1,07 & 0,61 \\
\hline $\boldsymbol{t}$ & $-2,444$ & $-2,354$ & $-3,527$ & $-3,016$ & $-2,035$ \\
\hline $\boldsymbol{d}$ & $-0,469$ & $-0,451$ & $-0,676$ & $-0,578$ & $-0,390$ \\
\hline Variance explained & $31,16 \%$ & $15,72 \%$ & $29,73 \%$ & $23,86 \%$ & $25,59 \%$ \\
\hline
\end{tabular}

Table 6. The Paternalistic Manager

\begin{tabular}{|l|c|c|c|c|c|c|}
\hline Significant Variable & Creativity & $\begin{array}{c}\text { Self- } \\
\text { confidence }\end{array}$ & Sadness & $\begin{array}{c}\text { Motivation: } \\
\text { glory }\end{array}$ & $\begin{array}{c}\text { Motivation: } \\
\text { independence }\end{array}$ \\
\hline General Mean & 3,74 & 3,48 & 2,16 & 0,31 & & 1,29 \\
\hline General sdeviation & 0,84 & 0,72 & 0,99 & 0,79 & & 1,30 \\
\hline Group Mean & 4,08 & 3,81 & 1,65 & 0,73 & & 0,73 \\
\hline Group sdeviation & 0,69 & 0,69 & 0,75 & 1,19 & & 1,08 \\
\hline $\boldsymbol{t}$ & 1,986 & 2,230 & $-2,542$ & 2,482 & & $-2,128$ \\
\hline
\end{tabular}




\begin{tabular}{|l|c|c|c|c|c|c|}
\hline $\boldsymbol{d}$ & 0,406 & 0,456 & $-0,520$ & 0,508 & & $-0,436$ \\
\hline Variance explained & $19,95 \%$ & $18,83 \%$ & $32,42 \%$ & $11,59 \%$ & & $21,83 \%$ \\
\hline
\end{tabular}

\begin{tabular}{|l|c|c|c|c|}
\hline $\begin{array}{l}\text { Significant } \\
\text { Variable }\end{array}$ & $\begin{array}{c}\text { Behavior: uncertainty } \\
\text { reduction }\end{array}$ & $\begin{array}{c}\text { Behavior: } \\
\text { gut feelings }\end{array}$ & $\begin{array}{c}\text { Behavior: } \\
\text { profit option }\end{array}$ & $\begin{array}{c}\text { Behavior : re- } \\
\text { examination }\end{array}$ \\
\hline General Mean & 0,90 & 2,28 & 1,81 & 1,91 \\
\hline General sdeviation & 1,18 & 0,88 & 1,04 & 0,98 \\
\hline Group Mean & 0,42 & 2,65 & 2,27 & 2,31 \\
\hline Group sdeviation & 0,76 & 0,75 & 1,12 & 1,09 \\
\hline $\boldsymbol{t}$ & $-2,022$ & 2,099 & 2,144 & 1,965 \\
\hline $\boldsymbol{d}$ & $-0,414$ & 0,430 & 0,439 & 0,402 \\
\hline Variance explained & $29,19 \%$ & $20,74 \%$ & $14,98 \%$ & $12,22 \%$ \\
\hline
\end{tabular}

\begin{tabular}{|l|c|c|c|c|c|}
\hline $\begin{array}{l}\text { Significant } \\
\text { Variable }\end{array}$ & $\begin{array}{c}\text { Behavior: } \\
\text { competence }\end{array}$ & $\begin{array}{c}\text { Behavior: } \\
\text { distinction }\end{array}$ & $\begin{array}{c}\text { Behavior: } \\
\text { lookout }\end{array}$ & $\begin{array}{c}\text { Circumstances: } \\
\text { rising sales }\end{array}$ & $\begin{array}{c}\text { Circumstances: } \\
\text { market expansion }\end{array}$ \\
\hline General Mean & 2,33 & 2,74 & 2,16 & 2,157 & 2,458 \\
\hline General sdeviation & 0,92 & 0,93 & 1,02 & 1,079 & 1,017 \\
\hline Group Mean & 2,77 & 3,23 & 2,69 & 2,81 & 2,88 \\
\hline Group sdeviation & 0,91 & 0,82 & 1,01 & 0,69 & 0,73 \\
\hline $\boldsymbol{t}$ & 2,335 & 2,602 & 2,551 & 3,017 & 2,070 \\
\hline $\boldsymbol{d}$ & 0,478 & 0,533 & 0,522 & 0,618 & 0,424 \\
\hline Variance explained & $19,57 \%$ & $27,37 \%$ & $22,39 \%$ & $47,77 \%$ & $26,81 \%$ \\
\hline
\end{tabular}

Table 7. The Hero

\begin{tabular}{|l|c|c|c|c|c|}
\hline $\begin{array}{l}\text { Significant } \\
\text { Variable }\end{array}$ & Hot-temper & $\begin{array}{c}\text { Motivation: } \\
\text { found empire }\end{array}$ & $\begin{array}{c}\text { Motivation: } \\
\text { Money }\end{array}$ & $\begin{array}{c}\text { Motivation: } \\
\text { glory }\end{array}$ & $\begin{array}{c}\text { Motivation: social } \\
\text { status }\end{array}$ \\
\hline General Mean & 2,39 & 1,69 & 0,19 & 0,31 & 0,26 \\
\hline General sdeviation & 1,14 & 1,25 & 0,65 & 0,79 & 0,76 \\
\hline Group Mean & 2,90 & 0,80 & 1,50 & 1,00 & 2,10 \\
\hline Group sdeviation & 1,37 & 1,20 & 1,32 & 1,41 & 1,25 \\
\hline $\boldsymbol{t}$ & 1,909 & $-3,088$ & 7,988 & 3,546 & 9,961 \\
\hline $\boldsymbol{d}$ & 0,441 & $-0,714$ & 1,847 & 0,820 & 2,303 \\
\hline Variance explained & $12,69 \%$ & $36,81 \%$ & $50,98 \%$ & $20,04 \%$ & $69,44 \%$ \\
\hline
\end{tabular}

\begin{tabular}{|l|c|c|c|c|}
\hline $\begin{array}{l}\text { Significant } \\
\text { Variable }\end{array}$ & $\begin{array}{c}\text { Motivation: } \\
\text { job love }\end{array}$ & $\begin{array}{c}\text { Motivation: } \\
\text { challenges }\end{array}$ & $\begin{array}{c}\text { Behavior: uncertainty } \\
\text { reduction }\end{array}$ & $\begin{array}{c}\text { Behavior: } \\
\text { distinction }\end{array}$ \\
\hline General Mean & 1,78 & 1,13 & 0,90 & 2,74 \\
\hline $\begin{array}{l}\text { General } \\
\text { sdeviation }\end{array}$ & 1,27 & 1,25 & 1,18 & 0,93 \\
\hline Group Mean & 0,60 & 0,60 & 1,90 & 3,25 \\
\hline Group sdeviation & 1,05 & 1,14 & 1,07 & 0,85 \\
\hline $\boldsymbol{t}$ & $-4,060$ & $-1,844$ & 3,686 & 2,384 \\
\hline
\end{tabular}




\begin{tabular}{|l|c|c|c|c|}
\hline $\boldsymbol{d}$ & $-0,938$ & $-0,426$ & 0,852 & 0,551 \\
\hline Variance explained & $57,24 \%$ & $18,47 \%$ & $47,85 \%$ & $27,45 \%$ \\
\hline
\end{tabular}

\begin{tabular}{|l|c|c|c|c|c|}
\hline $\begin{array}{l}\text { Significant } \\
\text { Variable }\end{array}$ & $\begin{array}{c}\text { Behavior: } \\
\text { reexamination }\end{array}$ & $\begin{array}{c}\text { Circumstances } \\
\text { :falling profits }\end{array}$ & $\begin{array}{c}\text { Circumstances: } \\
\text { falling shares }\end{array}$ & $\begin{array}{c}\text { Circumstances: } \\
\text { expert forecast }\end{array}$ \\
\hline General Mean & 1,91 & 1,608 & 1,652 & & 0,683 \\
\hline General sdeviation & 0,98 & 1,155 & 1,159 & & 0,920 \\
\hline Group Mean & 2,35 & 2,15 & 2,17 & & 1,10 \\
\hline Group sdeviation & 0,93 & 1,18 & 1,10 & & 1,29 \\
\hline $\boldsymbol{t}$ & 1,948 & 2,027 & 1,933 & & 1,904 \\
\hline $\boldsymbol{d}$ & 0,450 & 0,469 & 0,447 & & 0,440 \\
\hline Variance explained & $18,96 \%$ & $18,12 \%$ & $20,54 \%$ & & $9,86 \%$ \\
\hline
\end{tabular}

Table 8. The Mogul

\begin{tabular}{|l|c|c|c|c|c|c|}
\hline $\begin{array}{l}\text { Significant } \\
\text { Variable }\end{array}$ & Fearlessness & $\begin{array}{c}\text { Motivation: } \\
\text { found empire }\end{array}$ & $\begin{array}{c}\text { Motivation: } \\
\text { transform }\end{array}$ & $\begin{array}{c}\text { Motivation: } \\
\text { innovate }\end{array}$ & $\begin{array}{c}\text { Motivation: } \\
\text { challenges }\end{array}$ & $\begin{array}{c}\text { Motivation: } \\
\text { self-realization }\end{array}$ \\
\hline General Mean & 3,88 & 1,69 & 0,70 & 0,62 & 1,13 & 0,58 \\
\hline General sdeviation & 0,77 & 1,25 & 1,07 & 1,05 & 1,25 & 1,01 \\
\hline Group Mean & 3,52 & 2,48 & 1,62 & 1,14 & 1,86 & 1,14 \\
\hline Group sdeviation & 0,60 & 1,03 & 1,43 & 1,28 & 1,31 & 1,39 \\
\hline $\boldsymbol{t}$ & $-2,170$ & 2,944 & 3,881 & 2,272 & 2,685 & 2,510 \\
\hline $\boldsymbol{d}$ & $-0,470$ & 0,638 & 0,841 & 0,492 & 0,582 & 0,544 \\
\hline Variance explained & $26,91 \%$ & $37,93 \%$ & $30,22 \%$ & $14,98 \%$ & $24,31 \%$ & $14,71 \%$ \\
\hline
\end{tabular}

\begin{tabular}{|l|c|c|c|c|c|}
\hline Significant Variable & Education & Circumstances: & Circumstances: & Circumstances: & \\
falling sales & falling profits & falling shares & \\
\hline General Mean & 3,65 & 1,660 & 1,608 & 1,652 & \\
\hline General sdeviation & 1,60 & 1,190 & 1,155 & 1,159 & \\
\hline Group Mean & 4,38 & 2,29 & 2,14 & 2,24 & \\
\hline Group sdeviation & 2,01 & 0,96 & 1,11 & 1,04 & \\
\hline $\boldsymbol{t}$ & 2,077 & 2,354 & 2,055 & 2,252 & \\
\hline $\boldsymbol{d}$ & 0,450 & 0,532 & 0,464 & 0,509 & \\
\hline Variance explained & $12,17 \%$ & $31,02 \%$ & $19,65 \%$ & $24,85 \%$ & \\
\hline
\end{tabular}

Table 9. The Prophet

\begin{tabular}{|l|c|c|c|c|c|c|}
\hline $\begin{array}{l}\text { Significant } \\
\text { Variable }\end{array}$ & Creativity & $\begin{array}{c}\text { Self- } \\
\text { confidence }\end{array}$ & & $\begin{array}{c}\text { Motivation: } \\
\text { found empire }\end{array}$ & $\begin{array}{c}\text { Motivation: } \\
\text { money }\end{array}$ & $\begin{array}{c}\text { Motivation: } \\
\text { innovate }\end{array}$ \\
\hline General Mean & 3,74 & 3,48 & & 1,69 & 0,19 & 1,29 \\
\hline General sdeviation & 0,84 & 0,72 & & 1,25 & 0,65 & 1,30 \\
\hline Group Mean & 3,47 & 3,21 & & 1,23 & 0,00 & 0,65 \\
\hline Group sdeviation & 0,67 & 0,64 & & 1,25 & 0,00 & 0,92 \\
\hline
\end{tabular}




\begin{tabular}{|l|c|c|c|c|c|c|}
\hline $\boldsymbol{t}$ & $-2,051$ & $-2,333$ & & $-2,240$ & $-1,914$ & $-3,107$ \\
\hline $\boldsymbol{d}$ & $-0,335$ & $-0,381$ & & $-0,366$ & $-0,313$ & $-0,508$ \\
\hline Variance explained & $15,10 \%$ & $15,85 \%$ & & $12,30 \%$ & $100,00 \%$ & $33,42 \%$ \\
\hline
\end{tabular}

\begin{tabular}{|l|c|c|c|c|c|}
\hline $\begin{array}{l}\text { Significant } \\
\text { Variable }\end{array}$ & $\begin{array}{c}\text { Behavior: re- } \\
\text { examination }\end{array}$ & $\begin{array}{c}\text { Behavior: } \\
\text { competence }\end{array}$ & $\begin{array}{c}\text { Behavior: } \\
\text { distinction }\end{array}$ & $\begin{array}{c}\text { Behavior: gut } \\
\text { feelings }\end{array}$ & $\begin{array}{c}\text { Behavior: } \\
\text { experience }\end{array}$ \\
\hline General Mean & 1,91 & 2,33 & 2,74 & 2,28 & 2,59 \\
\hline General sdeviation & 0,98 & 0,92 & 0,93 & 0,88 & 0,71 \\
\hline Group Mean & 1,42 & 1,72 & 2,00 & 1,86 & 2,35 \\
\hline Group sdeviation & 0,98 & 0,85 & 0,93 & 0,91 & 0,72 \\
\hline $\boldsymbol{t}$ & $-3,068$ & $-4,088$ & $-4,873$ & $-2,903$ & $-2,075$ \\
\hline $\boldsymbol{d}$ & $-0,501$ & $-0,668$ & $-0,796$ & $-0,474$ & $-0,339$ \\
\hline Variance explained & $20,80 \%$ & $34,75 \%$ & $40,09 \%$ & $18,05 \%$ & $10,52 \%$ \\
\hline
\end{tabular}

\begin{tabular}{|l|c|c|c|c|c|}
\hline $\begin{array}{l}\text { Significant } \\
\text { Variable }\end{array}$ & $\begin{array}{c}\text { Behavior: } \\
\text { create market }\end{array}$ & $\begin{array}{c}\text { Behavior: } \\
\text { precise calculus }\end{array}$ & $\begin{array}{c}\text { Behavior: } \\
\text { profit options }\end{array}$ & $\begin{array}{c}\text { Behavior: on the } \\
\text { lookout }\end{array}$ & $\begin{array}{c}\text { Behavior: } \\
\text { innovation }\end{array}$ \\
\hline General Mean & 1,90 & 1,99 & 1,81 & 2,16 & 1,87 \\
\hline General sdeviation & 1,04 & 1,02 & 1,04 & 1,02 & 0,98 \\
\hline Group Mean & 1,49 & 1,36 & 1,23 & 1,56 & 1,42 \\
\hline Group sdeviation & 0,96 & 0,91 & 0,95 & 0,77 & 0,79 \\
\hline $\boldsymbol{t}$ & $-2,079$ & $-3,854$ & $-3,436$ & $-3,716$ & $-2,883$ \\
\hline $\boldsymbol{d}$ & $-0,399$ & 0,630 & 0,561 & $-0,607$ & $-0,471$ \\
\hline Variance explained & $16,14 \%$ & $34,37 \%$ & $28,03 \%$ & $39,31 \%$ & $25,30 \%$ \\
\hline
\end{tabular}

\begin{tabular}{|l|c|c|c|c|c|}
\hline $\begin{array}{l}\text { Significant } \\
\text { Variable }\end{array}$ & $\begin{array}{c}\text { Circumstances: } \\
\text { falling sales }\end{array}$ & $\begin{array}{c}\text { Circumstances: } \\
\text { falling profits }\end{array}$ & $\begin{array}{c}\text { Circumstances: } \\
\text { new contract }\end{array}$ & $\begin{array}{c}\text { Circumstances: } \\
\text { rising sales }\end{array}$ & $\begin{array}{c}\text { Circumstances: } \\
\text { rising profits }\end{array}$ \\
\hline General Mean & 1,660 & 1,608 & 2,430 & 2,157 & 2,109 \\
\hline General sdeviation & 1,190 & 1,155 & 1,032 & 1,079 & 1,140 \\
\hline Group Mean & 1,21 & 1,12 & 1,95 & 1,71 & 1,48 \\
\hline Group sdeviation & 0,97 & 0,96 & 0,96 & 0,89 & 0,99 \\
\hline $\boldsymbol{t}$ & $-2,370$ & $-2,659$ & $-2,861$ & $-2,566$ & $-3,471$ \\
\hline $\boldsymbol{d}$ & $-0,387$ & $-0,434$ & $-0,467$ & $-0,419$ & $-0,567$ \\
\hline Variance explained & $18,60 \%$ & $21,69 \%$ & $20,94 \%$ & $20,93 \%$ & $31,77 \%$ \\
\hline
\end{tabular}

\begin{tabular}{|l|c|c|c|}
\hline Significant Variable & $\begin{array}{c}\text { Circumstances: } \\
\text { market expansion }\end{array}$ & $\begin{array}{c}\text { Circumstances: } \\
\text { expert forecast }\end{array}$ & $\begin{array}{c}\text { Circumstances: } \\
\text { shareholders }\end{array}$ \\
\hline General Mean & 2,458 & 0,683 & 0,618 \\
\hline General sdeviation & 1,017 & 0,920 & 0,912 \\
\hline Group Mean & 2,02 & 0,38 & 0,26 \\
\hline Group sdeviation & 0,94 & 0,62 & 0,49 \\
\hline $\boldsymbol{t}$ & $-2,642$ & $-2,084$ & $-2,548$ \\
\hline
\end{tabular}




\begin{tabular}{|l|c|c|c|}
\hline $\boldsymbol{d}$ & $-0,432$ & $-0,340$ & $-0,416$ \\
\hline Variance explained & $19,13 \%$ & $20,15 \%$ & $36,17 \%$ \\
\hline
\end{tabular}

Table 10. The Craftsman

\begin{tabular}{|l|c|c|c|c|c|}
\hline Significant Variable & Optimism & Creativity & $\begin{array}{c}\text { Motivation: } \\
\text { innovate }\end{array}$ & $\begin{array}{c}\text { Motivation: } \\
\text { self-realization }\end{array}$ & Risk-taking \\
\hline General Mean & 3,49 & 3,74 & 1,29 & 0,58 & 4,35 \\
\hline General sdeviation & 0,80 & 0,84 & 1,30 & 1,01 & 1,27 \\
\hline Group Mean & 3,80 & 4,14 & 2,40 & 0,20 & 5,04 \\
\hline Group sdeviation & 0,80 & 0,73 & 0,91 & 0,63 & 1,22 \\
\hline $\boldsymbol{t}$ & 2,167 & 2,715 & 4,904 & $-2,173$ & 3,062 \\
\hline $\boldsymbol{d}$ & 0,388 & 0,486 & 0,877 & $-0,389$ & 0,548 \\
\hline Variance explained & $13,47 \%$ & $23,70 \%$ & $60,29 \%$ & $27,09 \%$ & $24,90 \%$ \\
\hline
\end{tabular}

\begin{tabular}{|l|c|c|c|c|c|}
\hline Significant Variable & $\begin{array}{c}\text { Behavior: } \\
\text { gut feelings }\end{array}$ & $\begin{array}{c}\text { Behavior: } \\
\text { market creation }\end{array}$ & $\begin{array}{c}\text { Behavior: } \\
\text { distinction }\end{array}$ & $\begin{array}{c}\text { Behavior: } \\
\text { on the lookout }\end{array}$ & $\begin{array}{c}\text { Behavior: edge } \\
\text { of innovation }\end{array}$ \\
\hline General Mean & 2,28 & 1,90 & 2,74 & 2,16 & 1,87 \\
\hline General sdeviation & 0,88 & 1,04 & 0,93 & 1,02 & 0,98 \\
\hline Group Mean & 2,57 & 2,34 & 3,26 & 2,94 & 2,89 \\
\hline Group sdeviation & 0,65 & 1,03 & 0,70 & 0,94 & 0,87 \\
\hline $\boldsymbol{t}$ & 1,896 & 2,383 & 3,181 & 4,325 & 5,861 \\
\hline $\boldsymbol{d}$ & 0,339 & 0,426 & 0,569 & 0,774 & 1,048 \\
\hline Variance explained & $16,94 \%$ & $16,06 \%$ & $35,94 \%$ & $41,78 \%$ & $58,57 \%$ \\
\hline
\end{tabular}

\begin{tabular}{|l|c|c|c|c|c|}
\hline $\begin{array}{l}\text { Significant } \\
\text { Variable }\end{array}$ & $\begin{array}{c}\text { Circumstances: } \\
\text { falling sales }\end{array}$ & $\begin{array}{c}\text { Circumstances: } \\
\text { falling profits }\end{array}$ & & $\begin{array}{c}\text { Circumstances: } \\
\text { financing poss. }\end{array}$ & $\begin{array}{c}\text { Circumstances: } \\
\text { market expansion }\end{array}$ \\
\hline General Mean & 1,660 & 1,608 & & 2,102 & 2,458 \\
\hline General sdeviation & 1,190 & 1,155 & & 1,081 & 1,017 \\
\hline Group Mean & 1,09 & 1,09 & & 1,71 & 3,03 \\
\hline Group sdeviation & 1,07 & 1,07 & & 1,25 & 0,92 \\
\hline $\boldsymbol{t}$ & $-2,726$ & $-2,547$ & & $-1,970$ & 3,165 \\
\hline $\boldsymbol{d}$ & $-0,488$ & $-0,456$ & & $-0,352$ & 0,566 \\
\hline Variance explained & $22,95 \%$ & $19,77 \%$ & & $9,01 \%$ & $28,23 \%$ \\
\hline
\end{tabular}

Table 11. The Inventor

\begin{tabular}{|l|c|c|c|c|c|c|}
\hline $\begin{array}{l}\text { Significant } \\
\text { Variable }\end{array}$ & Optimism & $\begin{array}{c}\text { Motivation: } \\
\text { transform }\end{array}$ & $\begin{array}{c}\text { Motivation: } \\
\text { challenges }\end{array}$ & $\begin{array}{c}\text { Motivation: } \\
\text { job love }\end{array}$ & Education & Risk-taking \\
\hline General Mean & 3,49 & 0,70 & 1,13 & 1,78 & 3,65 & 4,35 \\
\hline General sdeviation & 0,80 & 1,07 & 1,25 & 1,27 & 1,60 & 1,27 \\
\hline Group Mean & 3,82 & 1,23 & 1,82 & 0,50 & 4,64 & 5,39 \\
\hline Group sdeviation & 0,73 & 1,34 & 1,30 & 0,74 & 1,73 & 0,74 \\
\hline
\end{tabular}




\begin{tabular}{|l|c|c|c|c|c|c|}
\hline $\boldsymbol{t}$ & 1,865 & 2,187 & 2,484 & $-4,663$ & 2,772 & 3,776 \\
\hline $\boldsymbol{d}$ & 0,412 & 0,483 & 0,549 & $-1,031$ & 0,613 & 0,835 \\
\hline Variance explained & $16,71 \%$ & $13,36 \%$ & $21,99 \%$ & $74,95 \%$ & $24,46 \%$ & $66,30 \%$ \\
\hline
\end{tabular}

\begin{tabular}{|l|c|c|c|c|c|c|}
\hline $\begin{array}{l}\text { Significant } \\
\text { Variable }\end{array}$ & $\begin{array}{c}\text { Attitude } \\
\text { uncertainty }\end{array}$ & $\begin{array}{c}\text { Behavior: } \\
\text { gut feelings }\end{array}$ & $\begin{array}{c}\text { Behavior: } \\
\text { create market }\end{array}$ & $\begin{array}{c}\text { Circumstances: } \\
\text { falling sales }\end{array}$ & $\begin{array}{c}\text { Circumstances: } \\
\text { falling profits }\end{array}$ & $\begin{array}{c}\text { Circumstances: } \\
\text { falling shares }\end{array}$ \\
\hline General Mean & 1,80 & 2,28 & 1,90 & 1,660 & 1,608 & 1,652 \\
\hline General sdeviation & 0,65 & 0,88 & 1,04 & 1,190 & 1,155 & 1,159 \\
\hline Group Mean & 2,27 & 2,73 & 2,40 & 2,82 & 2,41 & 2,38 \\
\hline Group sdeviation & 0,46 & 0,55 & 0,82 & 1,05 & 1,18 & 1,12 \\
\hline $\boldsymbol{t}$ & 3,347 & 2,347 & 2,104 & 4,434 & 3,132 & 2,856 \\
\hline $\boldsymbol{d}$ & 0,740 & 0,519 & 0,486 & 0,9802 & 0,692 & 0,631 \\
\hline Variance explained & $51,82 \%$ & $39,77 \%$ & $28,09 \%$ & $55,91 \%$ & $32,50 \%$ & $31,90 \%$ \\
\hline
\end{tabular}

Table 12. The Gambler

\begin{tabular}{|l|c|c|c|c|c|c|c|}
\hline $\begin{array}{l}\text { Significant } \\
\text { Variable }\end{array}$ & Creativity & Hot-temper & Impulsivity & Risk-taking & $\begin{array}{c}\text { Motivation: } \\
\text { found empire }\end{array}$ & $\begin{array}{c}\text { Motivation: } \\
\text { money }\end{array}$ & $\begin{array}{c}\text { Motivation: } \\
\text { innovate }\end{array}$ \\
\hline General Mean & 3,74 & 2,39 & 2,51 & 4,35 & 1,69 & 0,19 & 0,62 \\
\hline General sdeviation & 0,84 & 1,14 & 1,01 & 1,27 & 1,25 & 0,65 & 1,05 \\
\hline Group Mean & 4,40 & 3,30 & 3,30 & 5,65 & 0,80 & $\mathbf{0 , 0 0}$ & 1,85 \\
\hline Group sdeviation & 0,50 & 1,08 & 0,92 & 0,83 & 1,11 & 0,00 & 1,23 \\
\hline $\boldsymbol{t}$ & 3,554 & 3,550 & 3,485 & 4,508 & $-3,178$ & $-1,338$ & 5,136 \\
\hline $\boldsymbol{d}$ & 0,803 & 0,802 & 0,787 & 1,042 & $-0,718$ & $-0,302$ & 1,160 \\
\hline Variance explained & $64,48 \%$ & $42,73 \%$ & $43,52 \%$ & $72,15 \%$ & $40,58 \%$ & $100,00 \%$ & $51,45 \%$ \\
\hline
\end{tabular}

\begin{tabular}{|l|c|c|c|c|c|}
\hline Significant Variable & $\begin{array}{c}\text { Motivation: } \\
\text { social status }\end{array}$ & $\begin{array}{c}\text { Motivation: } \\
\text { independence }\end{array}$ & $\begin{array}{c}\text { Technical } \\
\text { management }\end{array}$ & $\begin{array}{c}\text { Innovating } \\
\text { management }\end{array}$ & $\begin{array}{c}\text { Behavior: uncertainty } \\
\text { reduction }\end{array}$ \\
\hline General Mean & 0,26 & 1,29 & 1,95 & 1,85 & 0,90 \\
\hline General sdeviation & 0,76 & 1,30 & 0,81 & 0,81 & 1,18 \\
\hline Group Mean & $\mathbf{0 , 0 0}$ & 2,15 & 1,60 & 2,40 & 0,30 \\
\hline Group sdeviation & 0,00 & 1,09 & 0,82 & 0,94 & 0,57 \\
\hline $\boldsymbol{t}$ & $-1,565$ & 2,960 & $-1,914$ & 3,022 & $-2,253$ \\
\hline $\boldsymbol{d}$ & $-0,354$ & 0,669 & $-0,432$ & 0,683 & $-0,521$ \\
\hline Variance explained & $100,00 \%$ & $39,61 \%$ & $10,78 \%$ & $35,91 \%$ & $53,73 \%$ \\
\hline
\end{tabular}

\begin{tabular}{|c|c|c|c|c|c|}
\hline Significant Variable & \begin{tabular}{|c|} 
Behavior: \\
precise calculus
\end{tabular} & $\begin{array}{c}\text { Behavior: } \\
\text { profit options }\end{array}$ & $\begin{array}{c}\text { Circumstances: } \\
\text { falling sales }\end{array}$ & $\begin{array}{c}\text { Circumstances: } \\
\text { falling profits } \\
\end{array}$ & $\begin{array}{c}\text { Circumstances: } \\
\text { falling shares }\end{array}$ \\
\hline General Mean & 1,99 & 1,81 & 1,660 & 1,608 & 1,652 \\
\hline General sdeviation & 1,02 & 1,04 & 1,190 & 1,155 & 1,159 \\
\hline Group Mean & 1,25 & 1,20 & 2,30 & 2,20 & 2,20 \\
\hline Group sdeviation & 0,79 & 0,95 & 1,03 & 0,89 & 0,89 \\
\hline
\end{tabular}




\begin{tabular}{|l|c|c|c|c|c|}
\hline $\boldsymbol{t}$ & $-3,178$ & $-2,550$ & 2,345 & 2,245 & 2,071 \\
\hline $\boldsymbol{d}$ & $-0,735$ & $-0,590$ & 0,542 & 0,519 & 0,479 \\
\hline Variance explained & $48,24 \%$ & $30,20 \%$ & $28,85 \%$ & $31,56 \%$ & $28,32 \%$ \\
\hline
\end{tabular}

Table 13. The Explorer

\begin{tabular}{|c|c|c|c|c|c|c|c|c|c|c|c|}
\hline Variable & Neo & Builder & Admin & Pater & Hero & Mogul & Prophet & Craft & Invent & Gambler & Explorer \\
\hline Self-real & & + & & & & & + & & - & & \\
\hline Indep & & -- & ++ & & - & & & & & & ++ \\
\hline Vision & & & & & & & + & & & + & \\
\hline Innovate & & -- & & & & & + & -- & +++ & & ++ \\
\hline Glory & & & & & + & ++ & & & & & \\
\hline Challenge & & - & & & & - & + & & & + & \\
\hline Found & & + & & & & -- & ++ & - & & & -- \\
\hline Job love & & +++ & + & & - & -- & & & & -- & \\
\hline Status & & & - & & & +++ & & & & & - \\
\hline Money & & & + & & & ++ & & & & & - \\
\hline Education & & & - & & & & + & & & + & \\
\hline \multicolumn{12}{|l|}{ Manager } \\
\hline Executive & & & & - & & & & & & & \\
\hline \multicolumn{12}{|l|}{ Pragmatic } \\
\hline Technical & & + & & & & & & & & & - \\
\hline Innovative & & -- & & - & & & & & & & ++ \\
\hline Risk-taking & & - & - & -- & & & & & + & +++ & +++ \\
\hline Uncertainty & -- & & & & & & & & & ++ & \\
\hline Optimism & & & & & & & & & + & + & \\
\hline Self-conf & & & & & + & & & - & & & \\
\hline Impulsivity & & & & & & & & & & & ++ \\
\hline Creativity & & - & & & + & & & - & + & & +++ \\
\hline Sadness & & & & & - & & & & & & \\
\hline Fearless & ++ & & & & & & - & & & & \\
\hline \multicolumn{12}{|l|}{ Regret } \\
\hline Hot-temper & & & & - & & + & & & & & ++ \\
\hline
\end{tabular}

Table 14. Cross-comparison between groups of entrepreneurs on the basis of classification variables

Legend: a simple "+" is indicative of a significant positive $t$ Test, while a "++" is indicative of a very significant feature (above $1 / 3$ of the variance explained) and "+++" is reserved to features where the membership to the group accounts for more than $60 \%$ of the variance. Conversely, the meaning of "-" and “-_"are quite obvious. Execptions are "social status" and "money", since the general mean was very low.

\begin{tabular}{|l|c|c|c|c|c|c|c|c|c|c|c|}
\hline Variable & Neo & Builder & Admin & Pater & Hero & Mogul & Prophet & Craft & Invent & Gambler & Explorer \\
\hline Calculus & +++ & & & & & & & -- & & & -- \\
\hline
\end{tabular}




\begin{tabular}{|c|c|c|c|c|c|c|c|c|c|c|c|}
\hline Options & + & & & & & & & - & & & - \\
\hline Experts & + & & & & & & & & & & \\
\hline Re-examin & ++ & & & - & & + & & -- & & & \\
\hline Gut feeling & & & & - & & & & - & + & + & \\
\hline Distinction & & & & - & + & + & & -- & ++ & & \\
\hline Creation & & & & & & & & - & + & + & \\
\hline Securing & & & ++ & + & - & ++ & & & & & -- \\
\hline Lookout & & & & & + & & & -- & ++ & & \\
\hline Edge innov & & - & & & & & & - & ++ & & \\
\hline Staff & & + & & & + & & & -- & & & \\
\hline Rise profit & ++ & ++ & + & - & & & & - & & & \\
\hline Rise sales & & + & & - & ++ & & & - & & & \\
\hline Interest rate & + & + & + & - & & & & & & & \\
\hline Self-finance & & + & + & - & & & & & & & \\
\hline New client & & & & & & & & - & & & \\
\hline Financing & & & ++ & & & & & & - & & \\
\hline Forecasts & & & & - & & + & & - & & & \\
\hline Alternative & ++ & & & - & & & & & & & \\
\hline Expansion & & & & -- & + & & & - & + & & \\
\hline Shareholders & + & & & & & & & - & & & \\
\hline Profit fall & & & - & - & & + & + & - & - & + & + \\
\hline Sales fall & & + & - & - & & & + & - & - & ++ & + \\
\hline Shares fall & & & - & - & & + & + & & & + & + \\
\hline Cost & & + & & & & & & & & & \\
\hline
\end{tabular}

Table 15. Cross-comparison between groups of entrepreneurs on the basis of the dependent variables 